\title{
NATURBANIZATION AND URBAN - RURAL DYNAMICS IN SPAIN: CASE STUDY OF NEW RURAL LANDSCAPES IN ANDALUSIA AND CATALONIA
}

\author{
Marta Pallarès-Blanch ${ }^{1}$, Maria-José Prados ${ }^{2}$, Antoni Francesc Tulla ${ }^{3}$
}

Received 1 February 2013; Accepted 13 December 2013

\begin{abstract}
The early 20th century saw the beginning of a process of urbanizing rural space (Berry, 1976a; 1976b), described as counter-urbanization (Champion, 1989). The creation of Protected Natural Areas (PNAs) has defined some rural spaces, relatively far from large urban metropolitan areas, where the ecological and scenic value is a magnet for urbanization (Prados, 2005). Thus, PNAs make rural areas more attractive to new economic and leisure activities and can promote a more positive type of development that has been called naturbanization (Prados, 2009). We address this topic in six sections: (1) Introduction; (2) Conceptual framework of naturbanization; (3) Methodology to analyse the process of naturbanization; (4) Processes of naturbanization in Andalusia and in Catalonia; (5) Comparative analysis of two case studies, and (6) Conclusions and Recommendations.
\end{abstract}

Key words: Naturbanization; Protected Natural Areas (PNAs) in mountain areas, Urban-rural dynamics, Landscape changes; rural migrations, Sierra Nevada Protected Natural Area (Andalusia); Aigüestortes i Estany de Sant Maurici National Park (Catalonia), Cadí-Moixeró Natural Park and Alt Pirineu Natural Park (Catalonia)

Resumen:Se ha desarrollado un proceso de urbanización del espacio rural desde principios del siglo XX (Berry, 1976a; 1976b) descrito como la "counterurbanización" (Champion, 1989). La creación de los espacios naturales protegidos (ENP) ha delimitado unos espacios rurales, relativamente alejados de las grandes conurbaciones urbanas, donde la valoración ecológica y paisajística genera, en algunos casos, una atracción urbanizadora (Prados, 2005). De este modo, los ENP hacen más atractivo al espacio rural y promueven la naturbanización (Prados, 2009). En esta presentación trataremos el tema en seis apartados: (i) Introducción (ii) El marco conceptual de la naturbanización; (iii) La metodología para analizar la naturbanización; (iv) Los procesos de naturbanización en Andalucía y en Cataluña;

\footnotetext{
1 Marta Pallarès-Blanch, Department of Geography, Universitat Autònoma de Barcelona, Campus de Bellaterra, Edifici B, Barcelona, Spain; e-mail: marta.pallares@gmail.com; Her work has been done within the framework of the UAB Ph.D. Program in Geography.

2 Prof. Maria-José Prados Velasco, Department of Human Geography, Faculty of Geography and History, University of Sevilla, C/S. Fernando, 41004 Sevilla, Spain; e-mail: mjprados@us.es

${ }^{3}$ Prof. Antoni Francesc Tulla Pujol, Department of Geography, Universitat Autònoma de Barcelona, Campus de Bellaterra, Edifici B, Barcelona, Spain; e-mail: antoni.tulla@uab.cat
} 
(v) El análisis comparativo de los dos casos estudiados y, finalmente, (vi) presentamos conclusiones y propuestas de implementación.

Palabras clave: Naturbanization; Espacios Naturales Protegidos (ENP) en áreas de montaña; cambios del paisaje, migraciones rurales; Espacio Natural Protegido de Sierra Nevada (Andalucía); Parque Nacional de Aigüestortes i Estany de Sant Maurici, Parque Natural de Cadí-Moixeró y Parque Natural del Alt Pirineu (Cataluña).

\section{Introduction}

A portion of society increasingly values quality of life and landscape as they become scarcer due to intensive urbanization in metropolitan areas. This sensitivity about the natural environment has led to official measures to preserve and protect it. One of the most important and especially visible of these initiatives is the declaration of protected natural areas (PNAs), which has established national parks and natural parks.

Preservation often exists where industrial activity was impossible, and this is why the parks are generally located in zones far from urban centres. Although PNAs are frequently located in areas considered marginal from the standpoint of production, the extraordinary social impact of environmental questions, especially with respect to environmental preservation, has led to new pressures on these territories.

On the one hand, the creation of PNAs has added value to some rural spaces, even those relatively far from large urban metropolitan areas, where the ecological and scenic value is a magnet for urbanization (Prados 2005). On the other hand, the cities' relative loss of attractiveness as residential and production nuclei represents a new logic in the motivations behind population shifts. Indeed, the ecological value of PNAs makes the rural space more attractive to urban dwellers and this can mean new development opportunities and threats for these areas (Johnson \& Rasker 1995, Deller et. al. 2001, Krannich \& Petrzelka 2003, Loffler \& Steinecke 2006, Moss 2006, Saint Onge et. al. 2007, Sedlacek et. al. 2009, Prados 2009).

Within this framework, naturbanization is a term that identifies, describes and analyses urbanization processes in the areas influenced by national or natural parks (Prados 2009). Formulated as a specialized concept in urban-rural dynamics theories, naturbanization is based on the new territorial dynamics in the impact areas of European National and Natural Parks (Elbersen 2001, Prados \& Tulla 2009) and can be understood as a modality of the counterurbanization process (Prados 2005; Prados 2009). The processes of naturbanization begin when new residential settlements motivated by environmental value are constructed in a protected area with singularly beautiful natural ecosystems and cultural landscapes (Corraliza et al. 2002, Gude et al. 2006), or within the vicinity. Without a doubt, these new settlements stimulate rural multifunctionality and the creation of new jobs (Johnson \& Rasker 1995, Kaplan \& Austin 2004). Nonetheless, the same factors that attract and boost rural development can lead to unintended consequences, such as increases in the built surface area, resource pressure and decline, changing land uses that degenerate the landscape, etc. (Lonsdale \& Holmes 1981, Ghose 2004). Therefore, naturbanization as a result of valuing the natural environment and landscape is one exponent of contemporary rural repopulation that must be carefully considered. This study takes an in-depth look at the phenomenon of naturbanization in two of Spain's Autonomous Communities, Andalusia and Catalonia. Both case studies, the Sierra Nevada and the Catalan High Pyrenees, respectively, resulted from research projects ${ }^{4}$ funded by Spain's National Science and Technology Plan. In this paper we develop a preliminary approach to assessing the pros and cons of the naturbanization process.

\footnotetext{
${ }^{4}$ CSO2011-28480 "Territorios en la Frontera. Costes ambientales y beneficios territoriales de los procesos de naturbanizacion (PI: María J. Prados), and CSO 2009-08271 "Los paisajes de las áreas de montaña. Patrones de gestión y ocupación del territorio" (PI: Antoni F. Tulla).
} 


\section{The conceptual framework of naturbanization}

At the beginning of the $21^{\text {st }}$ century, rural areas in southern European countries are experiencing a progressive tertiarisation of their socio-economy and territory (Dijst et al. 2005 in Pallarès-Blanch, 2012). This is the outcome of the rural restructuring process initiated in response to the effects of the new global market, mainly since the 1980s, together with European Community (EC) rural policy reforms that have had severe effects on traditionally agrarian areas, especially in many parts of southern Europe (Paniagua 2002b). In many areas, globalization and liberalization of markets has made agrarian activity insufficient even for subsistence. The results of rural restructuring differ between rural spaces with competitive farms, mainly in areas strongly specialized in the agribusiness sector, and those with scattered medium-size farms, often in mountainous regions and/or remote areas where the major conservation areas are located (Woods 2011). In these areas, agriculture and livestock production are progressively being transformed into an integrated system in which added value is the key to gaining economic benefits, including the preparation of high-quality, often organic, foods and development of proximity networks of consumption as well as production (Sage 2003, Morris 2011). This process is promoted institutionally under the general umbrella of rural development policies. Rural development promotion is articulated through several packages of programs and grants which belong to the different working lines of the EC rural policy (support for organic conversion, young farmers, technology transfer, craft food production, entrepreneurship, etc.). Therefore, the agricultural sector is (and increasingly should be) a strategic sector in efforts to invigorate these rural areas, considering its conservation role in maintaining the landscape, sustaining biodiversity and protecting natural and cultural heritage (Tolón \& Lastra 2009b). Many remote and mountainous areas, particularly in southern European countries like Spain, perform these functions (Otterstrom \& Shumway 2003; Pintos 2005; Gude et. al. 2006; Loffler 2006; Moss 2006; Pallarès-Blanch 2009; Pallarès-Blanch 2012, Tulla et. al. 2012).

In the context of urban-rural dynamics, the unique characteristics of the countryside have become economic 'commodities' for which an increasing demand has evolved (Marsden 2003, Cloke 2006 and Elbersen 2005). This commodification has meant that rural areas gradually become integrated into urban society, representing important reserve space for the expanding activities in urban areas (Elbersen 2005). Consequently, one of the effects of current urban-rural dynamics is the attractiveness of Protected Natural Areas (PNA) as places not only to visit but to live nearby. Attracting a segment of the population that wishes to work, relax and live close to or within a Natural or National Park has recently been studied using the lens of naturbanization (Prados \& Cunningham 2002; Prados 2009; Prados \& Tulla 2009; Prados \& del Valle 2010). Applying this concept, the processes of urbanization related to PNA are broadly defined to include a desire for a new residential environment, the renewal of traditional economic activities, new economic activities based upon heritage elements, population growth, land use changes, landscape degradation, etc. (Prados 2009).

\section{Naturbanization: Starting with counter-urbanization studies}

The theoretical framework of naturbanization must be found in the counter-urbanization literature background. The early 20th century saw the beginning of a process of urbanizing rural space, described as counterurbanization (Berry 1976a, 1976b, 1978), which has spread throughout North America and Europe with greater or lesser intensity. The concept of counterurbanization established by B. Berry was expanded by A. Champion (1989). Both authors highlighted a change in the urbanization processes in countries like the United States of America and Great Britain. In the words of Berry, it constituted "a process of de-concentration of the population; which implies a movement from a state of higher concentration to a state of lower concentration" (Berry 1976a: 20). The original idea of counter-urbanization had certain parallels with Spanish urban theories at the beginnings of the last century. The concepts of 'rururbanization' of the Catalan Ildefons Cerdà and the 'linear city' of Arturo Soria tried to design newly deconcentrated urban models as new forms of urbanization (de Terán 1982). The new concept of counter-urbanization referred to the fact that population de-concentration contradicted the classic models in contemporary geography, based on the central role of 
primary cities in the Theory of Central Location and on the Range-Size Rule (Prados, 2009). Additionally, the identification of a structure of flows in the urban-rural movements was implicit in the counter-urbanization concept, representing a great advance in traditional spatial analysis (Prados 2009). The flows structure was clearly adopted in the rural studies corpus. In the early 1990s, literature on rural systems identified two key factors emerging among the numerous aspects of the intensification of urban-rural dynamics: the general improvement of communication facilities, which goes hand-in-hand with urban deconcentration, and the increasing environmental awareness associated with the growth of services, particularly related to tourism (Bowler 1992, Harper 1991). These two dimensions --urban deconcentration and increasing environmental awareness- define the central structure of the rural systems during recent decades and reveal the impacts of the change processes taking place (PallarèsBlanch 2012).

The spatial flows perspective and the intensification of urban-rural dynamics can be found clearly reflected in Friedmann's definition of urbanization, which has three elements. First, the demographic component: "the increasing concentration of people in settlements with high population densities is higher than in the areas surrounding them" (Friedmann 2002: 3-5). Second, urbanization comprises economic activities, normally associated with cities but also with urban elements in the countryside, like central functions of trade and services, which are part of the 'urban fabric' (Lefebvre 2003, pp 3-4 in Friedmann 2002: 3-5). Third, urbanization embraces sociocultural aspects related to some participation in urban ways of life: "sociocultural urbanization is a dimension that, like the economic, is no longer exclusively associated with the city as a built environment" (Friedmann 2002: 3-5).

\section{Beyond the Urban-Rural Dichotomy}

At the end of the 20th century, the urbanization of society, including the diffusion of the urban economy and urban way of life (even in the most remote areas), has reduced the traditional distinction between urban and rural populations (Pumain 2004). This is particularly relevant in Europe, where there is a long and continuous history in human settlements. European urbanization is characterized by high population density (around 100/ $\mathrm{km}^{2}$ ) with less concentrated distribution than in other parts of the world (Pumain, 2004). Nonetheless, European countries have no common statistical definition of an "urban" settlement. This may be due to the fact that there are no uniform representations of town or city throughout Europe, despite the shared history and many common physical and cultural similarities (Pumain 2004). Urban territories in Europe are often defined by legal decisions. In Spain and Italy, the urban character is defined by a threshold size of the resident population: all municipalities with more than 10,000 population are urban, the remainder are considered rural. Many efforts have been dedicated to defining rural areas by other quantitative parameters (Cloke 1977, 1985, 2006). Nonetheless, rural studies, particularly those derived from geography and sociology disciplines; continue to highlight the need to develop more accurate theoretical frameworks to understand socio-spatial transformations in rural areas. This has been particularly evident during recent decades, when rural restructuring processes have almost blurred the traditional ways of looking at rural areas (Pumain 2004). In this sense, naturbanization refers to the métissage character of the spaces rather than taking the traditional dichotomous urban vs. rural approach (Jaillet 2004).

\section{Naturbanization, Environmental Element and Urban-Rural Dynamics Theories}

The structure of flows has been a crucial a starting point to understand new and intensified urban-rural dynamics in the post-productive context. Within this frame, migration to rural areas appeared as a clear expression of the profound transformations after 1970 redistribution trends. A number of concepts have emerged around this new process: counter-urbanization, coreperiphery migration, dispersal, resurgence, population turnaround, turnaround migration, population reversal, rural renaissance, urban exodus, etc. (Solana 2008; 2012). The increasing mobility of the population and the consequent extension of the living space of the city's area of influence has been one of the most fundamental elements to begin to explain urban-rural migration patterns (Solana 2008). In this context, it is important to differentiate between counterurbanization, which constitutes the revival and new dynamics of more remote rural areas, and 
suburbs and peri-urbanization, which simply extend the city into rural areas close to metropolitan centres (Solana 2008, 2012).

Two groups of social analysts have arisen from this distinction. On the one hand, there are those who relate these patterns of population location with economic activity (Cloke, 1985; Cloke \& Thrift, 1990; Fielding, 1982, Frey, 1993; Halliday \& Coombes 1995, Murdoch, 1998). This line took the spatial division of labour as the cause that originates restructuring, not only of labour markets but of the spatial distribution of occupations. From this angle, rural areas might benefit from the dispersion of work outward from metropolitan urban centres and suburbs. Subsequent studies focus on the ways in which natural amenities, especially public lands and other protected areas, stimulate economic growth by attracting individuals, small businesses, and retirees with non-earnings income, contributing to a variety of multiplier effects (Rasker \& Hansen 2000). In a more recent review of rural in-migration studies, economic gain is indicated as a key motivator, in combination with natural and cultural amenities (Moss 2006). Other studies find correlation between in-migration and growth in local and regional economic activity (Müller 2006), and consequently observe that local jobs are created by in-migrants as new local entrepreneurs (Thompson 2006). However, not all the effects of urban-rural migration are desirable. Among them, two are highlighted; the significant rise in the price of housing and land (Ghose 2004; Loffler and Steinecke 2007; Solana 2010) and cultural clashes (Krannich \& Petrzelka 2003, Saint Onge et al. 2007).

Another set of explanations for migration to rural areas emphasizes factors related to society, culture and, more specifically, to new residential preferences. Newcomers seek a new type of housing that fulfils certain requirements of quality and location, in many cases responding to changes throughout the course of life and the formation of families, with the consequent demand for more space and the emergence of other residential and environmental aspirations (Fielding 1992, 1993). However, this has been branded as a biased approach because it ignores the conflict and contradictions between the preferences of individuals and the constraints imposed by the housing market (Solana 2008). Other studies have adopted the quality of life and environmental quality concepts as the main drivers of residential changes and increased migration to rural areas (Champion et. al. 1998; Findlay et. al. 1993; Halfacree 1996; Williams \& Jobes 1990). The environmental concept, comprising physical and social aspects, celebrates the "rural idyll". This expression from English literature refers to an essential, inseparable part of the cultural heritage of a country (Bunce 1994; Champion et. al. 1998; Cloke et. al. 1995; Fabes et. al. 1983; Gorton et. al. 1998; Mingay, 1994).

Whatever the case may be, as a result of the complex amalgam of factors involved in the maturity of cities and in population movements and residential choices, the term counterurbanization was revised by other authors (Hoggart 1997, 2007; Mitchell 2004; Halfacree 1994, 1997, 2012; Paniagua 2008, among many others - see Solana 2008, 2010). All of these efforts to update and enrich the concept of counter-urbanization have made important contributions to our understanding of urban-rural dynamics and their socio-demographic and spatial implications. One of the most relevant for our approach to the generation of naturbanization processes in Spain is a case study presented by K. Hoggart (1997), which shows that counter-urbanization can be present at the same time as the depopulation process. This parallel phenomenon was identified in rural migrations in Andalusia, taken as an example of one peripheral European zone. This is especially valuable considering that the most abundant literature on urban-rural migrations is produced from a British perspective. The need to distinguish between core and peripheral rural areas has been emphasized (Halfacree 2001; Paniagua 2002a), owing to the need to increase the scientific precision of studies on counterurbanization and the new social classes, but also with the purpose of studying urbanrural migrants in a purely rural context (Paniagua 2008). In this sense, PNA attractiveness adds the pull factor of rural areas with specific natural values to the traditional vision of counterurbanization as a process of urban deconcentration (Prados 2009, 2010). Consequently, including PNA effects in the urban-rural dynamic highlights the potential PNA role in rural development strategies and for environmental preservation of rural natural areas (Prados 2009; 2010). 
Mitchell (2004) offers a deep epistemological and semantic examination of the concept of counter-urbanization, presenting one of the widest literature reviews to date on rural dynamics. She points out several key questions. First, the deconcentration term embraced two crucial elements, physical movement of urban residents to the countryside and the shift of the settlement system to greater deconcentration. Here, Mitchell considers that counterurbanization is an imprecise term that led to myriad interpretations of the crucial phrase'population deconcentration' (Berry 1976a: 17 in Mitchell 2004: 27); she notes, however, that this was understandable given the novelty of the phenomenon when it was defined. Second, a large part of Berry's 1976 article was devoted to a discussion of the movement of metropolitan residents to more natural environments (deconcentration). Third, the large body of literature on the subject of post-1970 redistribution trends (mainly summarised by Champion 1995) can be used as an organizational structure to understand the various approaches. Indeed, the research carried out over the last thirty years on counter-urbanization processes, and their effects on population settlement models, has allowed the identification and analysis of this phenomenon. At the same time, new elements have been progressively introduced (Prados 2009) so that, within the entire original framework of post-1970 redistribution trends, other essential contributions have emerged along the same lines. These contributions highlight the necessity of attending to urban-rural dynamics by including new factors as they become visible on the 'new rurality ${ }^{15}$ scene (Champion \& Hugo 2004; Kay 2008) and advocate for a multidimensional approach to conceptualize rurality. This approach must reflect economic, institutional, and cultural realities, alongside standard ecological criteria based on population size, density, and accessibility (Brown \& Cromartie 2004), and recognize the importance of imaginative or social understandings of the rural context (Little 1999; Halfacree 2007).

The potential attraction of the rural environment for the new middle classes linked to the specific valuation and social representation of rurality is one of the specific topics raised in the postproductivist context (Halfacree 1994, 1997). Nonetheless, the rural or environmental dimension of counterurbanization has been little studied in analyses of the reasons for migrating from urban to rural areas (Paniagua 2008). This explains the lesser importance assigned to environmental concerns or to issues associated with the rural context (tranquillity, peace, lower population density, strong community relations, etc.) in studies of migration to rural areas (Halfacree 1994 in Paniagua 2008). Surely, this can be at least partially explained from a Spanish perspective by three interrelated methodological considerations. Most rural studies have been done within the socioeconomic realm; consequently, the environmental aspect has been generally taken for granted by many social scientists. Secondly, specialists in conservation spaces are strongly focused on land management issues and stewardship. Finally, tourism impacts are treated from a managerial or cultural perspective.

Given these conditions, the naturbanization concept proposes the territorial frame formed by areas close to or included in a PNA as a reference to analyse rural development processes, expressed in the renewal of traditional economic activities, in the emergence of new economic activities based upon heritage elements, and in population growth and land use changes (Prados 2009). Hence, naturbanization incorporates into urban-rural dynamics theories the fact that the important natural and cultural heritage of rural areas is often encapsulated in the PNA designation (Prados 2009; Prados 2005; Jaillet 2004).

\footnotetext{
${ }^{5}$ The term 'new rurality' is used here with the broadest sense indicated by Kay (2008) as 'an umbrella concept used to refer to any new developments in the rural areas or any issues which had previously been neglected or insufficiently emphasized by previous frameworks" (Kay 2008: 920). However, we subscribe to the definition given later by the author, having revised the concept in the same paper: 'The new rurality analysts thus seek to find new ways of securing sustainable livelihoods for peasants and rural workers and, in the communitarian version, envision a post-capitalist transformation of the countryside so as to achieve the goals of equity, food sovereignty, sustainability and empowerment' (Kay 2008:937). Although post-capitalist context effects in the rurality have been fully studied (Arkleton Trust 1985, Gasson 1986, Marsden 1990, Murdoch 1993), the 'new rurality' term specifically recognizes the determinant role of globalization dynamics in structuring rural economies.
} 


\section{Naturbanization and amenity migration studies}

Naturbanization studies take PNA values as a reference for an explanation of new patterns and preferences in the residential mobility of a specific population segment (Brown \& Wardell 1980; Camarero 1993; Elbersen \& Prados 1999; Elbersen 2001; Ghose 2004; Elbersen 2005; Prados 2009; Prados \& del Valle 2010). Environmental elements are a key factor of investigation in most of the amenity migration literature as well (Sofranko \& Williams 1980; Rasker \& Hansen 2000; Otterstrom and Shumway 2003; Chipeniuk 2006; Müller 2006; Saint Onge et. al. 2007). Although both lines share background studies, they have developed different discourses. Thus, the attraction of and impacts on the rural natural environment are significantly developed in the field of amenity migration studies, which is particularly rooted in North American research and often associated with tourism and recreation studies. Certainly, most of the literature on amenity-seeking migration is about the USA, and especially the mountains to the west (Moss 2006). An important part of amenity migration research also originated in concern for sociocultural change, commoditization of culture, and the natural environment (Chipeniuk 2004, Moss 2006).

According to Gosnell \& Abrams (2011), the amenity migration concept includes a wide variety of activities taking place in a differentiated social landscape that is itself the result of multiple migration phenomena, globalization, and uneven development. While not an entirely novel phenomenon (Sofranko \& Williams 1980; Price 1997), amenity migration studies have been especially meaningful since migration patterns are leaving an increasingly large footprint on rural landscapes worldwide (Gosnell \& Abrams 2011; Moss, 2006). In these studies, specific expectations regarding the natural and cultural environment of rural areas are shown to be major drivers of the migration phenomenon (Deller et al. 2001). The connections with Western Europe are not so frequent (Gosnell \& Abrams, 2011) despite the convergence of subjects of study. Some of the nexus can be found in second-home studies (Paniagua, 2002b; Elbersen 2005; Müller 2006) and in research on processes of "counterurbanization" (Halfacree 1994; Boyle and Halfacree 1998; Dahms and McComb 1999; Otterstrom and Shumway 2003; Mitchell 2004; Loffler and Steinecke 2006, 2007). Clearly, the existence of these two different intellectual paths can be explained, among other reasons, by different transformative processes and their implications for the dynamics of rural places worldwide. This also includes semantic issues, considering that the term 'amenity' is infrequently used in the European literature.

Conversely, post-capitalist effects in north-European rurality have been specifically linked with rural restructuring processes (Arkleton Trust 1985, Gasson 1986, Marsden 1990, Murdoch 1993, Woods 2003, 2007) that have taken a particular form -and could not do otherwiseaccording to the specificities of each context and its geo-historical, sociocultural, political and economic facets. Gosnell \& Abrams (2011) respond to this conglomerate of domains, specialities and disciplines, providing a useful review of diverse conceptualizations of amenity migration. They consider that, "as just one dimension of the broader transition to postproductivism in the global north, amenity migration can be thought of as a function of the interplay between macro-scale forces associated with global trade liberalization and the actions of individual human agents in search of idyllic rural spaces within which to live and recreate' (Lowe et al. 1993; Halfacree 2006 in Gosnell \& Abrams 2011, p. 314). Given these differences in disciplinary and national scholarship Gosnell \& Abrams propose several lines of research that span the limits of this segmentation. First of all, the environmental governance approach can tap questions about the ways in which increasing rural heterogeneity and new mixes of financial, social, and intellectual capital might catalyse the cultivation of new forms of economic development on agricultural landscapes around the world. From our point of view, this subject would in turn embrace land use planning as a very consistent professional domain on the methodological side, albeit not always as integrated with innovative approaches as is, for example, governance. Second, the authors refer to potentially "post-productivist" economic opportunities intersecting with amenity migration and demographic change. Third, they advocate for more qualitative research on the social dimensions of urbanization to improve understanding of emerging management challenges and opportunities in these working landscapes. In this line, they mention the added value of including new dimensions of 
theoretical inquiry into the changing rural space, such as taking into consideration "radical rural" examples and gentrification by gay and lesbian in-migrants.

\section{Naturbanization: specific contributions}

In contrast to the processes of urban sprawl associated with counterurbanization, the naturbanization approach insists on valuing the natural environment and landscape surroundings as the central motivation of population movement. Thus, the naturbanization approach is based on the assumption that the presence of a PNA is important in residential choices (Elbersen \& Prados 1999; Elbersen 2001; Elbersen 2005). Preliminary research demonstrates the relationship between PNAs and residential activity in The Netherlands, Spain and Great Britain. The presence of a PNA or the quality of the physical environment (which is enhanced by the presence of a PNA), rather than new job opportunities, proved to be the considerations most frequently involved in newcomer selection of a residential environment. In the Dutch and British study areas, environmental factors were determinant, although these were less important in the Spanish case. The studies cited conclude that the presence of PNAs is an important factor in residential mobility in Mediterranean countries, but not as much as in northern Europe; however, its importance is expected to increase. This behaviour is evident in PNAs located on the seacoast (e.g., Doñana National Park in Spain) and/or close to large metropolitan areas (e.g., Kampinoski National Park in Poland). On the other hand, remote spaces like mountain areas in Andalusia seem to be less related to these dynamics than the coastal parks because the latter are more affected by the dynamics of tourism, construction or new agriculture and the associated industrial activity (Pallarès-Blanch 2012). Nonetheless, this does not mean that these processes are absent from mountain park areas, such as Portugal's Peneda-Gêres National Park (Lourenço et al. 2009) or Spain's Sierra Nevada National Park (Prados \& Giusti 2010) or in the Catalan Pyrenees (Tulla et. al 2009). Therefore, despite their less dynamic profile, protected mountain areas are of great interest in the study of naturbanization because they are generally more vulnerable spaces (Debarbieux \& Price 2012).

Certainly, despite the still striking regional disparities between European countries, the increasing role of nature --whether valued as part of heritage or as an asset- is a common and recent key element in the new rurality scene. Even more, the environmental aspect currently is a strategic factor, though rural communitarian policy moved from a production orientation towards a more territorial approach, in an effort to stir economic, social and environmental development in the countryside (Ramos et. al. 2005).

It is also essential to consider the increasing importance of territory as a mediator of communication and of the processes of consolidating or creating local identities. Moreover, many PNA, particularly Natural Parks, configure an arena in which natural, social, spiritual and cultural values congregate to form working landscapes. In them, natural values and cultural landscape "acquire an important protagonism, because they are, per se, a cultural display window" (Nogué \& de San Eugenio 2009, p. 52).

Consequently, studies of rural idealization, demographic dispersion, new ruralism, working landscapes or gentrification of the rural population are also necessary points of reference for the study of naturbanization (Nogué 1988; Phillips 2004; van Dam et al. 2002; Ghose 2004; Paniagua 2008). Of equal importance are the contributions in the realm of rural development, particularly increased tourism and its urbanistic repercussions (Fuguita \& Johansen 1984; García \& García 2002; Cànoves et al. 2006). In the same way, rural housing (Marcouiller et. al. 2011), rural housing policies (Norris et. al. 2010) and second-home debates estimating the balance of benefits and disadvantages (Gallent et. al. 2005; Halfacree 2012) are relevant to the naturbanization approach. All these debates can be particularly helpful with respect to remote and mountain areas where naturbanization can be major contributor to regional and local economies (Bell \& Ward 2000; Hall \& Müller 2004; Norris et. al. 2010). No less important is research on competing uses within PNAs, the impact of human activity in the territory, and the implementation of plans for sustainable development ${ }^{6}$ (Pintos 2005). In addition to their role

\footnotetext{
${ }^{6}$ We have adopted the definition of sustainable development provided by the European Commission. See: http://ec.europa.eu/environment/eussd/ [28-10-13]. Rather than develop an operational definition of this concept, we
} 
in preservation and protection, PNAs also carry out a demonstrative function (Martínez \& Romero 2003). In the social realm, the natural heritage of the PNA, along with the cultural heritage, undeniably brings a sense of identity to the surrounding rural spaces (Martínez \& Romero 2003). All of this contributes to a reinforcement of the protagonism that both the National and Natural Parks exercise in the realm of environmental preservation. Without a doubt, this process of heritage-building, together with the work of the PNA management structure, helps to make the natural values of PNAs visible and to show the results of preservation policies (Bourdeau 2012). Nonetheless, PNAs --and especially the parks-- compile, catalyse, and make evident the divergent interests of the local community, the scientific community, and political perspectives, as well as the discrepancies between these groups (Santamarina 2005). Therefore, studies on naturbanization processes attempt to provide a framework of analysis by which to examine emerging demographic, economic and spatial trends in areas with significant PNAs. These are not isolated spaces but rather heritage reserves that can enhance local sustainable socioeconomic development, particularly in remote areas that may offer very limited job opportunities (Naughton-Treves 2005). However, the naturbanization process can have negative implications for ecological, landscape and social values if it is not predicted and regulated. This is why the process needs to be explored.

\section{Methodology to analyse the process of naturbanization}

This study was made possible by a combination of diverse information sources. We would highlight the important secondary sources used. First, we reviewed academic publications focussing on spatial analysis of urban-rural residential mobility in the broadest sense. Second, we studied institutional and legal documents related to the PNAs, as well as public policy documents concerning sustainable rural development and tourism in the PNAs. Third, we consulted statistical data made available from the population and housing census of each study area. It was not possible to conduct precise comparative analyses because of the heterogeneity of the statistical treatments and data analysis. Quantitative methods were used to evaluate the extent of the naturbanization process in both of the study areas, to the extent that measureable data were available.

Conceptually, naturbanization is a particular situation in the urban-rural migration process which focuses on the attraction of population to rural areas with recognized natural and environmental value. It is a category of counterurbanization, as is the peri-urban phenomenon that relates to the city fringe where urban diffusion coexists with agrarian activities (Pahl, 1966). Naturbanization goes deeply into the causes of attraction to rural areas with recognized environmental, natural and cultural values, and at the same time analyses the territorial and landscape consequences of this process (Prados \& del Valle, 2010: 437). Therefore, methodologically the naturbanization approach first identifies a flow of new residents who are attracted to the presence of natural and environmental resources with scenic values, normally PNAs (Prados 2009). The first indication of naturbanization is population growth due to positive migration, of both national and foreign origin, and possibly related to an interest in the area's environmental and landscape values. This motivation is associated with new labour perspectives that are often related to a desire to participate in a more sustainable development model than is generally encountered in cities (Elbersen 2005; Prados 2009). Therefore, the second indication of naturbanization is related to the increase in principal homes and the appearance of new productive activities oriented toward "consumption of nature" (Prados 2009).

Second homes can be defined as an 'occasional residence of a household that usually lives elsewhere and which is primarily used for recreation purposes' (Shucksmith, 1983: 174 in

have selected the conceptual framework provided by the following sources: 1) Nechodom (2005) on the need to engage institutions and environmental management agencies in defining the concept, 2) Tolón \& Lastra (2009b) on "new-endogenous development" that takes advantage of the endogenous potential for the development of social capital and of local participatory democracy to establish processes of sustainable rural development and 3) Spanish law (45/2007, BOE 299, 14 December 2007, p. 51339) concerning sustainable development in rural areas, which states that all rural policy must seek better territorial integration of rural zones, facilitating a complementary relationship between rural and urban areas". 
Halfacree, 2012: 214). We analysed the evolution of seasonal populations as an indicator of the non-permanent population (Bell \& Ward 2000), although second homes sometimes imply new permanent residents. Whether permanently or temporarily used, second homes have noticeable effects on the territory and destination communities (Bell \& Ward 2000; Casado-Diaz 2004; Gallent al. al. 2005; Norris et. al. 2010; Halfacree 2012). Although Spain's large increase in second homes is in part related to the real estate boom, natural values matter in the housing market (Casado-Diaz 2004). Rurality and nature are, then, implicitly represented in the sales promotion of housing in rural areas close to PNAs. Although expanding the presence of second homes contributes fewer local development opportunities than do permanent residences (Elbersen 2005; Prados \& Tulla 2009; Tulla et. al. 2009; Pallarès-Blanch 2012; Tulla et. al. 2012), second homes can be a basic indicator of the attractiveness of a place. For this purpose, we used the data on seasonal population ${ }^{7}$ provided by the Catalan Statistics Institute ${ }^{8}$; unfortunately, the corresponding data are not available for Andalusia. Instead, we used orthophoto analysis to assess the increase in built environment over time in the case study from Andalusia.

The third indicator of naturbanization is the positive impact of these new residents on sustainable local development, which is related to environmental preservation objectives (Prados 2009). These include, among others, recreational and leisure activities related to nature-based tourism and reactivation of economic endeavours of the crops and livestock sector (Prados, 2009; Prados, \& Giusti, 2010). This is reflected, for example, in the consolidation of a network of small producers and local residents engaged in sustainable local development processes. This comes together with the creation of local organizations created to support innovation, such as the regulatory boards for the Protected Geographical Indication and other quality designation regulations, as well as associations of producers and artisans. If the process of naturbanization is well integrated with local governance, the synergies that result have a positive effect on activities related to innovation and territorial embeddedness (Pallarès-Barberà \& Vera, 2000; 2001). At the same time, these synergies attract professionals and strengthen businesses founded on loyalty to a space (Pallarès-Barberà et al., 2004). We used qualitative data from secondary sources to implement this third indicator. The thorough review of literature helped to compensate, in part, for the lack of precise statistical data that could be compared for the two study areas.

\section{The processes of naturbanization in the High Catalan Pyrenees National and Natural Parks (Catalonia) and Sierra Nevada Protected Space (Andalusia).}

Research to date has established the existence of naturbanization processes near PNAs in Andalusia, beginning in the mid-1990s with a comparative analysis of the resident population in the Doñana National Park impact area (Elbersen \& Prados, 1999). Surveys indicated that the newcomers' arrival was motivated by the existence of residential areas with high natural

\footnotetext{
7 Annual Full-time Equivalent (AFTE) population data base (Catalan Statistics Institute). The unit of measure of seasonal population estimates is AFTE people. Every day that a person is present in a municipality is equivalent to 1/365 AFTE person. This seasonal population estimate is designed to represent the population burden each municipality supports. The seasonal population includes the following components, which correspond to the types of relationship people have with the town: 1) Principal residence: population residing in the town; 2) Second home: population staying in their own or others' houses or visiting family and friends. The sources used were the Population Census, Survey of living conditions and population habits and Catalan Travel Survey; 3) Tourism: (overnight stays in tourist establishments); 4) Labour mobility: inter-work (no overnight); and 5) Mobility studies: inter-mobility studies (no overnight). Not considered: Overnight movements not related to work or study (eg leisure, shopping).

${ }^{8}$ Data from Dwelling Census 1981; 1991; 2001 and Population and Dwellings Enquiry 2011 - (Enquesta de Població i habitatge 2011)- from Catalan Statistics Institute (www.idescat.cat); drawn from the Population and Dwellings Census, Spanish National Institute of Statistics (www.ine.es). The Census classifies types of dwellings as 'Family Dwellings' and 'Public Dwellings' (monasteries, prisons, other collective housing). 'Family Dwellings' are further categorized as 'Principal Dwellings' (Principal Conventional Dwellings and Accommodation sites) and 'Non Principal Dwellings' ('Second Dwellings' and 'Empty Dwellings'). In this classification 'Second Dwellings' statistics correspond to second homes and are defined as "Family dwelling temporarily used: weekends, holidays, etc...".

[http://www.idescat.cat/territ/BasicTerr?TCD $=20 \& V 3 D=39 \& V 4 D=164 \& Q \mid \& T C=5 \& V 0=2 \& V 1=04 \& V 3=1035 \& V 4=30 \& A$ LLINFO=TRUE\&PARENT $=25 \& C T X=B$ 14-08-13]
} 
values on their surroundings. Further research reported a majority trend toward population gains after decades of massive emigration and in areas in which the population was aging (Prados, 2005). The case studies demonstrated that despite continued population decline in these areas, the losses were not as great as in early periods of rural exodus (Prados, 2009). In Portugal, Peneda-Gêres National Park continued to lose population (Lourenço et al., 2009). In Poland's Kampinoski National Park, the situation is even more dramatic because of the relocation of broad sectors of the population outside of the protected area established by the creation of the park (Czerny et al., 2009). Secondly, studies have demonstrated that these population losses coexist with the arrival of an immigrant population and growth in the total number of residences (Prados, 2005; Barros, 2008; Doctor \& Prados, 2012).

In light of these results, this article undertakes a comparative analysis of naturbanization processes surrounding the national and natural parks in the mountains of Andalusia and Catalonia. The cases studied are the impact areas of the National and Natural Parks of the Sierra Nevada in Andalusia, defined as the Sierra Nevada Protected Space (SNPS), and the Aigüestortes-Sant Maurici National Park and Cadí-Moixeró and Alt Pirineu Natural Parks in Catalonia (see Figure 1 and Figure 2). The key variables are residential development and the attraction of new residents (Prados \& Tulla, 2009).

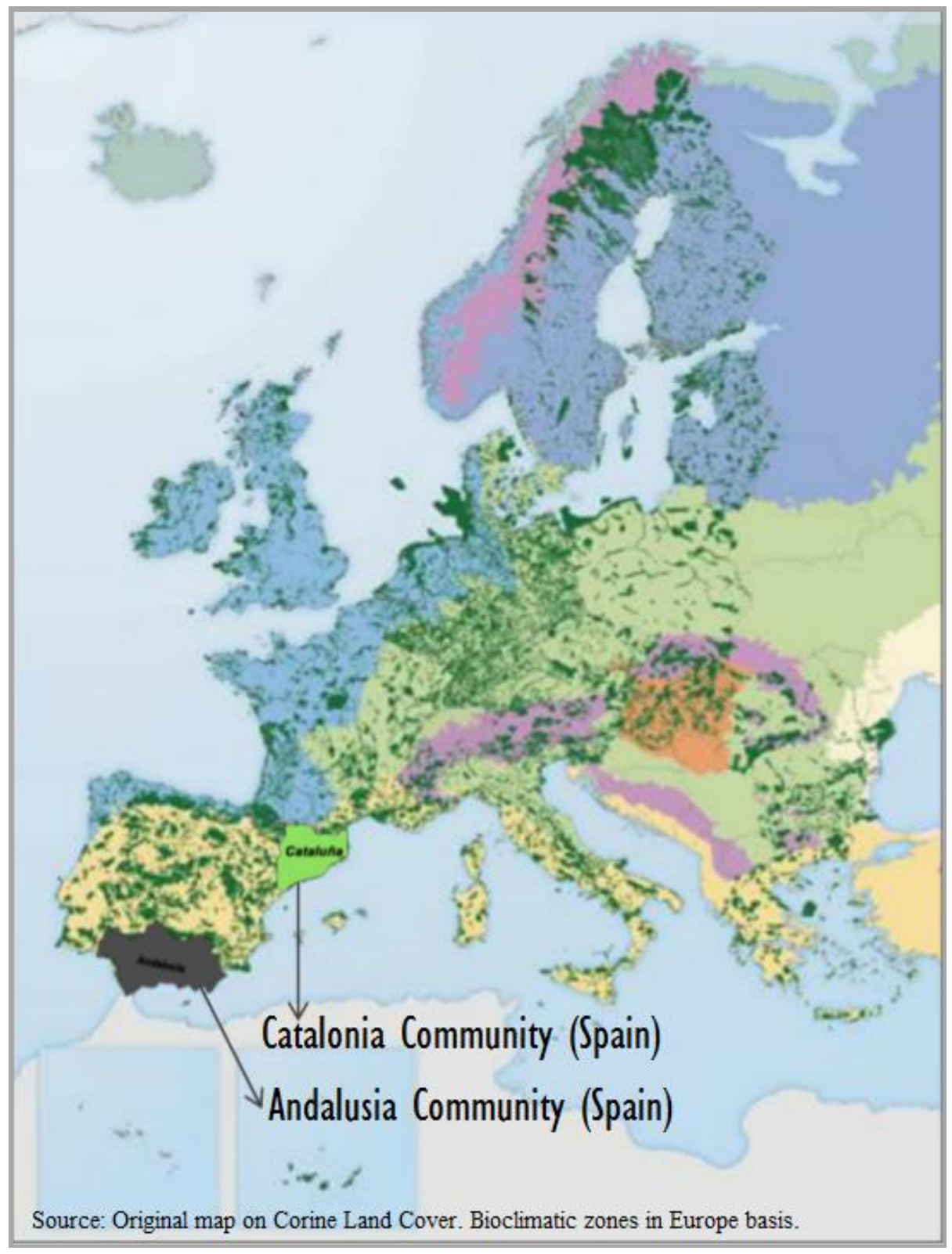

Fig 1. Location of the study areas. 

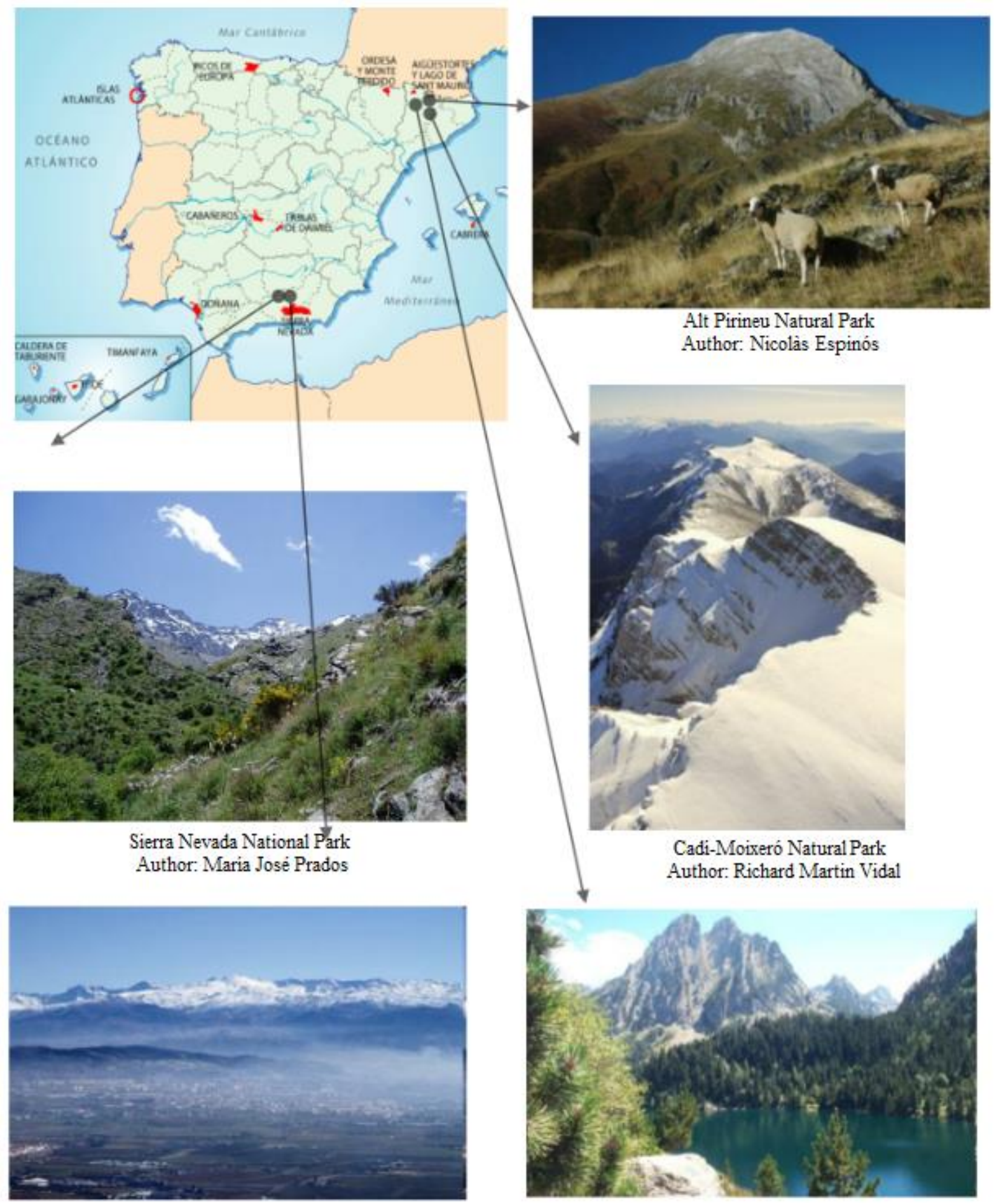

Sierra Nevada Natural Park Author: Natural Park Archive

Aigüestortes i Sant Maurici National Park Author: National Park Arhive

Fig 2. Location of protected natural areas in the study areas.

Sierra Nevada National Park Author: María José Prados

Cadí-Moixeró Natural Park Author: Richard Martin Vidal

Alt Pirineu Natural Park Author: Nicolàs Espinós

Aigüestortes i Sant Maurici National Park Author: National Park Arhive

Source: Original map on National Parks of Spanish Network basis. Photographs used with permission.

Sierra Nevada Natural Park Author: Natural Park Archive

National Parks governance is shared between the Spanish central government and regional authorities (Autonomous Communities), while Natural Parks are managed by the Autonomous Community. The area and limits of Natural Parks are discussed between regional government 
and local authorities in order to meet local land use goals, mainly in relation to future needs (Prados \& Tulla, 2009).

\subsection{Sierra Nevada Protected Space, Andalusia}

The SNPS, located in the southeast corner of Spain, is the second highest mountain range in Western Europe, after the Alps. It extends from the south-eastern part of Granada Province to the far western area of Almeria. It has a number of peaks above the altitude of 3000 meters, the highest being Mulhacén (3482 $\mathrm{m}$ ). In this natural space, the bioclimatic variations typical of high mountain areas are strengthened by the southern location, providing an exceptional refuge for biodiversity. Given the great variety of landscapes and the unique natural values, the area has received several types of protection: Biosphere Preserve (1986), Natural Park (1989) and National Park (1999). These various types of protection for the Sierra Nevada gave way to the PNA designation (2004) when the government of the Autonomous Community of Andalusia opted to combine the management of the natural spaces. The protected area of 86,432 hectares includes 60 municipalities, divided between two areas: counties in Almeria Province --Alpujarra-Alto Andarax and Río Nacimiento-- and four counties in Granada Province --La Alpujarra, Guadix-Marquesado, Occidente de Sierra Nevada and Valle de Lecrín (Figures 3 and 4).

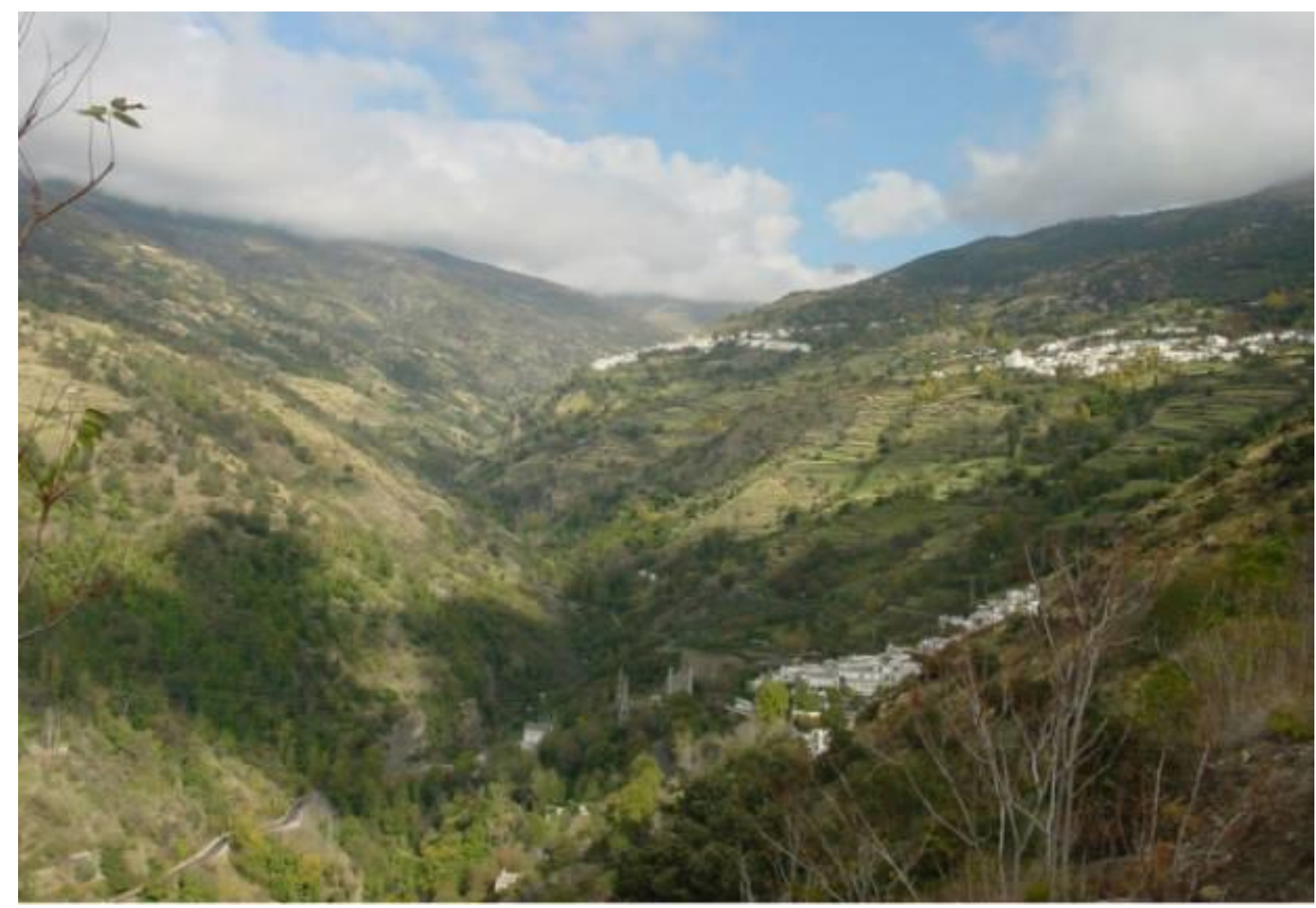

Fig 3. La Taha del Poqueira, with the towns of Pampaneria, Bubión and, in the distance, Capileria. Author María José Prados.

In 2011 the municipalities in this space had a population of 97,841 inhabitants. A major outmigration occurred during the 1960s and 1970s (Figures 5 and 6). The consequences were depopulation, loss of the younger population, decline in birth rate, and profound aging of the population (Prados \& del Valle, 2010). Beginning in the 1980s and 1990s these spaces converged in the attraction of new residents - whether permanent or temporary - and consequently, some population recovery occurred (Figures 7, 8, 9 and 10). 


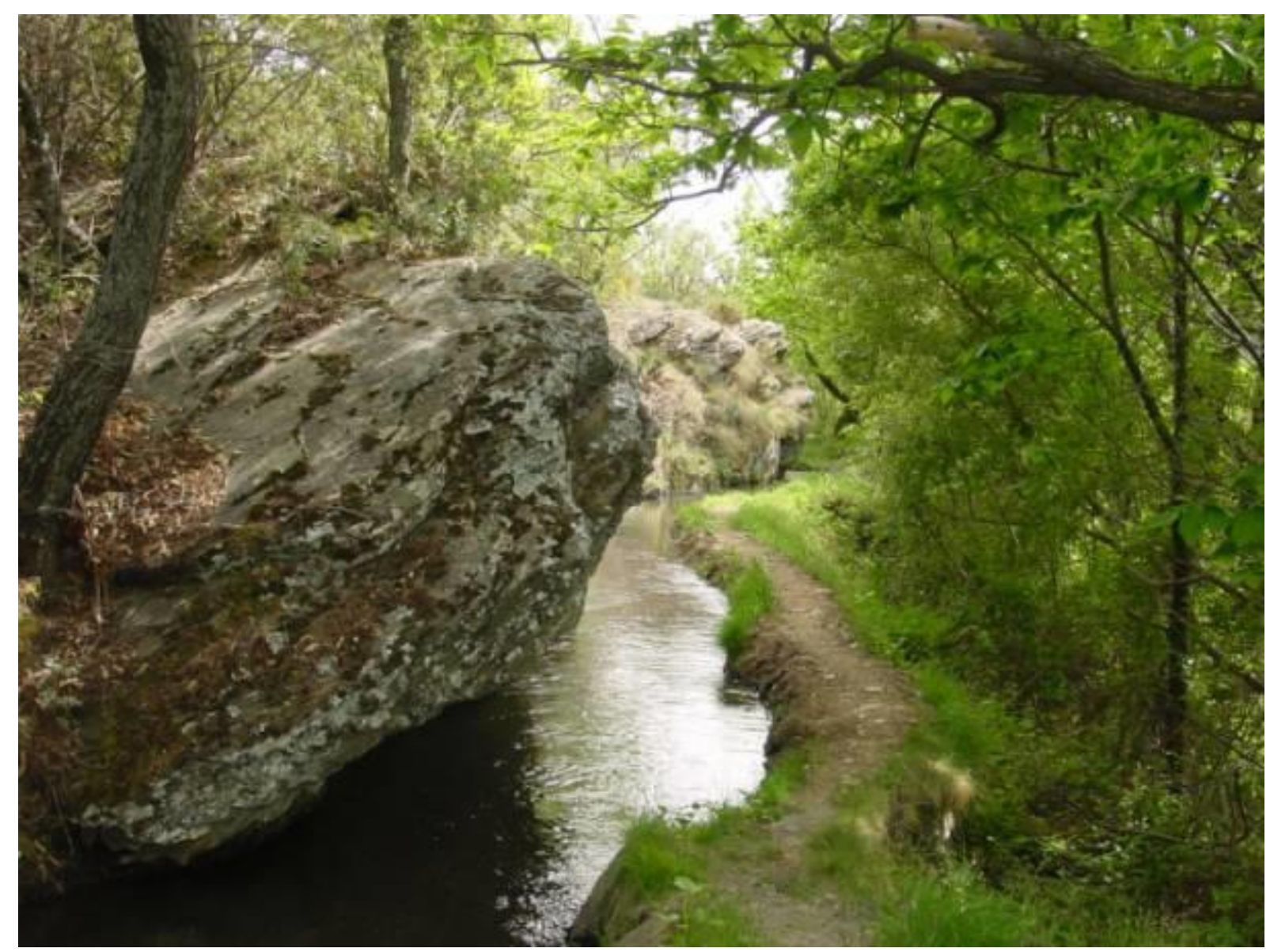

Fig 4. Acequia de Careo in Trevelez, SNPS, Andalusia. Author María José Prados.

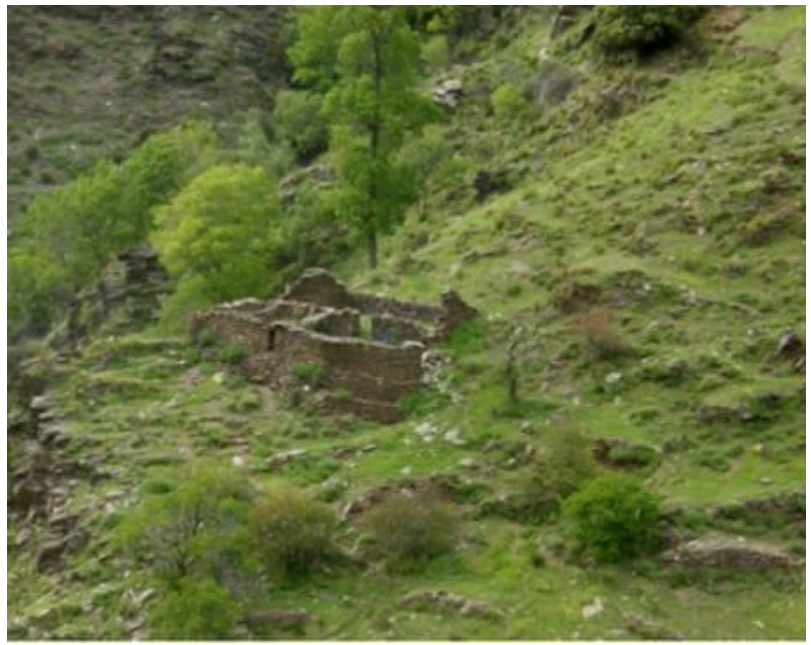

Fig 5. Abandoned cortijo (living quarters) in La Vereda de La Estrella, SNPS. Author: María José Prados.

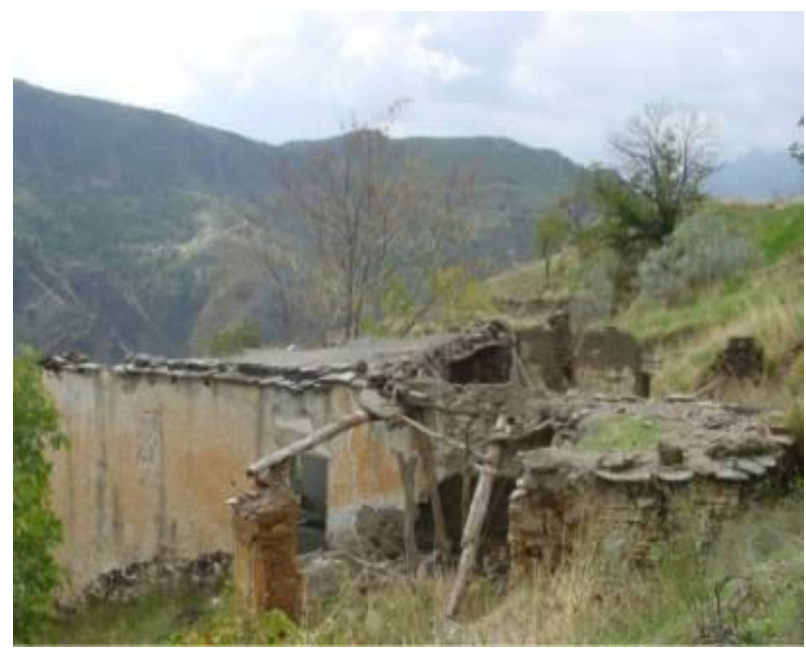

Fig 6. Abandoned cortijo (living quarters) in SNPS. Author: María José Prados. 


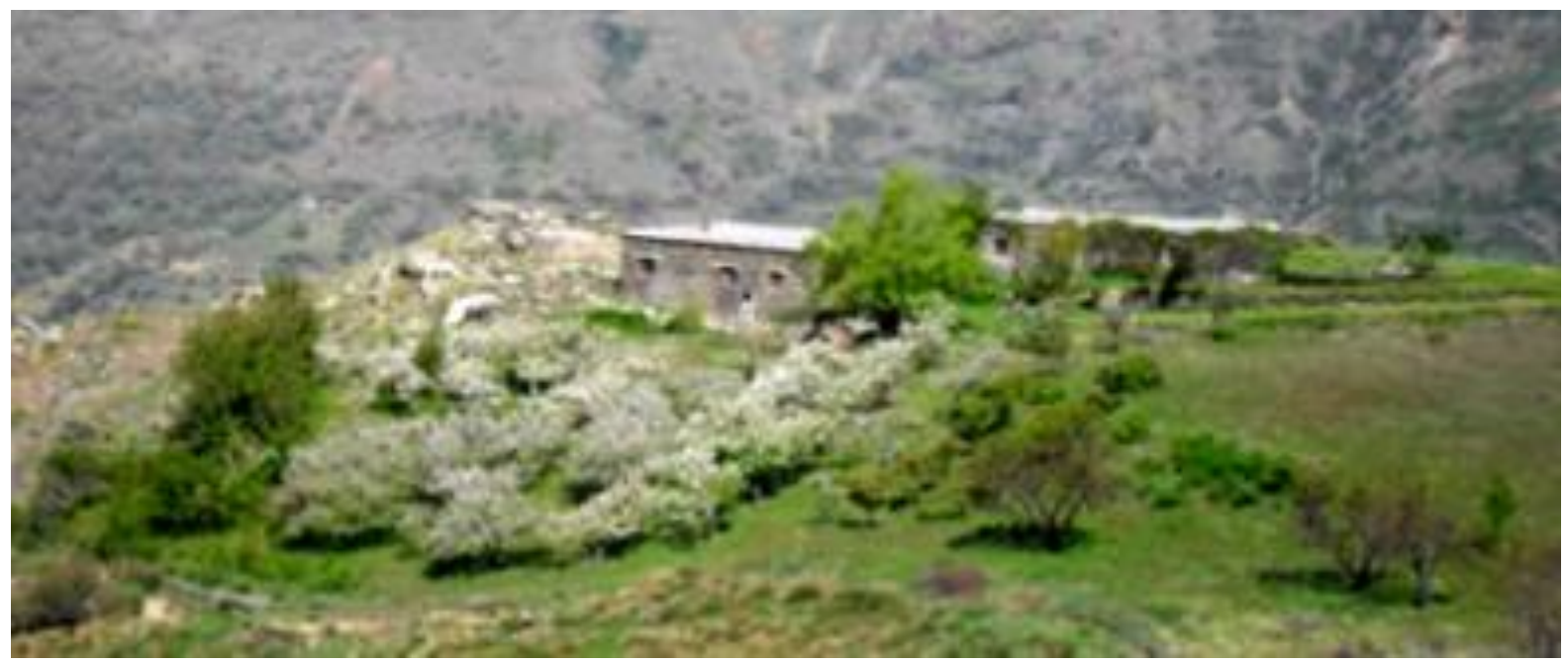

Fig 7. Traditional cortijo (living quarters) in SNPS. Author: Maria-José Prados.
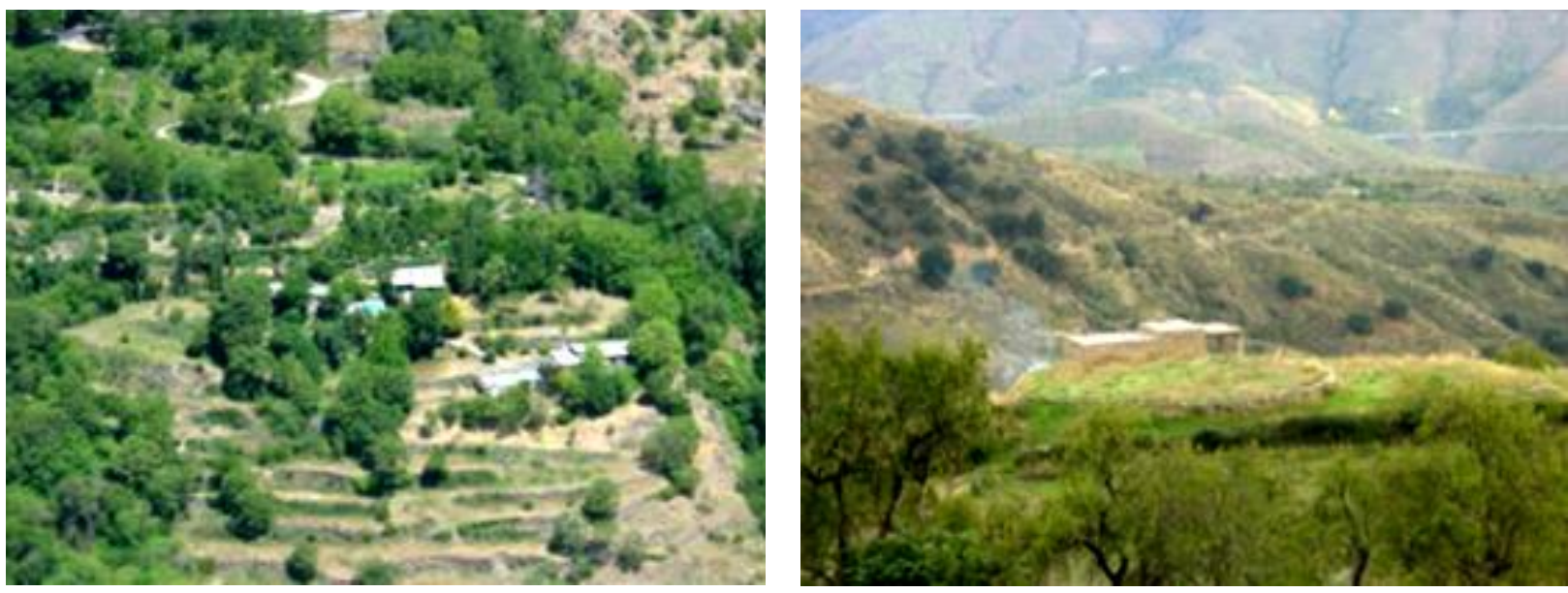

Fig 8. 9. Restored cortijos serving as second homes in the SNPS (Andalusia). Author: Maria-José Prados.

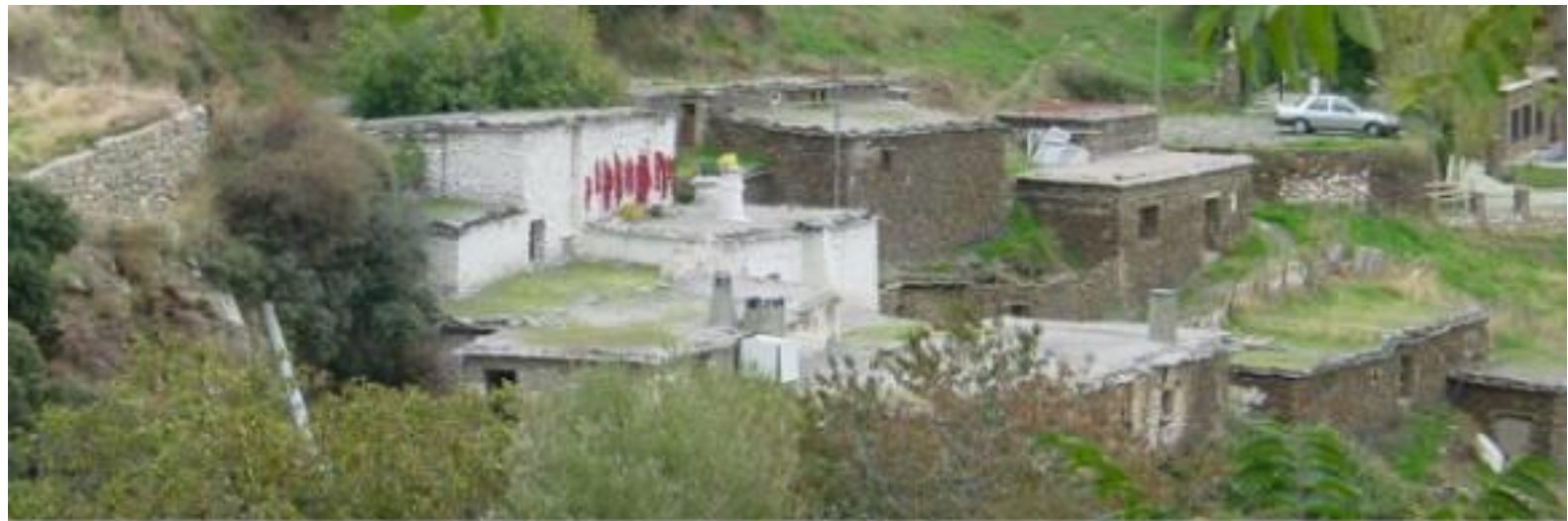

Fig 10. Restored cortijuelas in Busquistar, Alpujarra de Granada (SNPS, Andalusia). Author: María José Prados.

Municipalities within the SNPS have been losing population since 1950 (Table 1), reaching their lowest level in 1991 (73.9 compared to the 1950 index value). There was a major recovery of population by 2011 (89.1), exceeding the 1950 - 1970 index (81.7). This demographic recovery can be explained by the naturbanization process in the SNPS, influenced by growth in the Granada urban area and in neighbouring towns. 


\begin{tabular}{|c|c|c|c|c|c|c|c|c|c|c|}
\hline \multirow{3}{*}{ Area } & \multirow{2}{*}{\multicolumn{4}{|c|}{ TOTAL POPULATION }} & \multirow{2}{*}{\multicolumn{3}{|c|}{$\frac{\text { INTER-CENSUS }}{\text { RATE OF GROWTH }}$}} & \multirow{2}{*}{\multicolumn{3}{|c|}{ INDEX: $1950=100$}} \\
\hline & & & & & & & & & & \\
\hline & 1950 & 1970 & 1991 & 2011 & $1950-70$ & $1970-91$ & $1991-11$ & 1970 & 1991 & 2011 \\
\hline Total SNPS & 109,822 & 89,675 & 81,169 & 97,841 & -18.3 & -9.4 & 20.5 & 81.7 & 73.9 & 89.1 \\
\hline $\begin{array}{l}\text { Resto provincial sin } \\
\text { capitales }\end{array}$ & 909,479 & 803,44 & 830,827 & $1,196,921$ & -11.6 & 3.4 & 44.0 & 88.3 & 91.3 & 131.6 \\
\hline $\begin{array}{l}\text { Total províncias Granada } \\
\text { y Almeria }\end{array}$ & $1,140,354$ & $1,108,379$ & $1,278,278$ & $1,627,369$ & -2.8 & 15.3 & 27.3 & 97.2 & 112.0 & 142.7 \\
\hline Andalucía & $5,605,857$ & $5,971,277$ & $7,040,627$ & $8,424,102$ & 6.5 & 17.9 & 19.6 & 106.5 & 125.6 & 150.3 \\
\hline
\end{tabular}

Tab 1. Population distribution and changes in SNPS in relation to county and regional data, 1950 -2011. Data Source: Spain's National Institute of Statistics (Instituto Nacional de Estadística).

As shown in Figure 11, the Autonomous Community of Andalusia gained and the SNPS lost population at the same pace. In other words, the concentration of population in large urban areas and along the coast paralleled the depopulation of mountain areas. At the turn of the century, however, growth rates began to accelerate, and have increased over the past decade. Using the 1950 population as the baseline (index $=100$ ), Andalusia's position was 150.3 as of 2011 and that of the SNPS was 89.1. If we set the 2001 population as the baseline (index $=100$ ), the result is 114.5 for Andalusia and 113.0 for the SNPS, which more clearly demonstrates the importance of the demographic recovery.

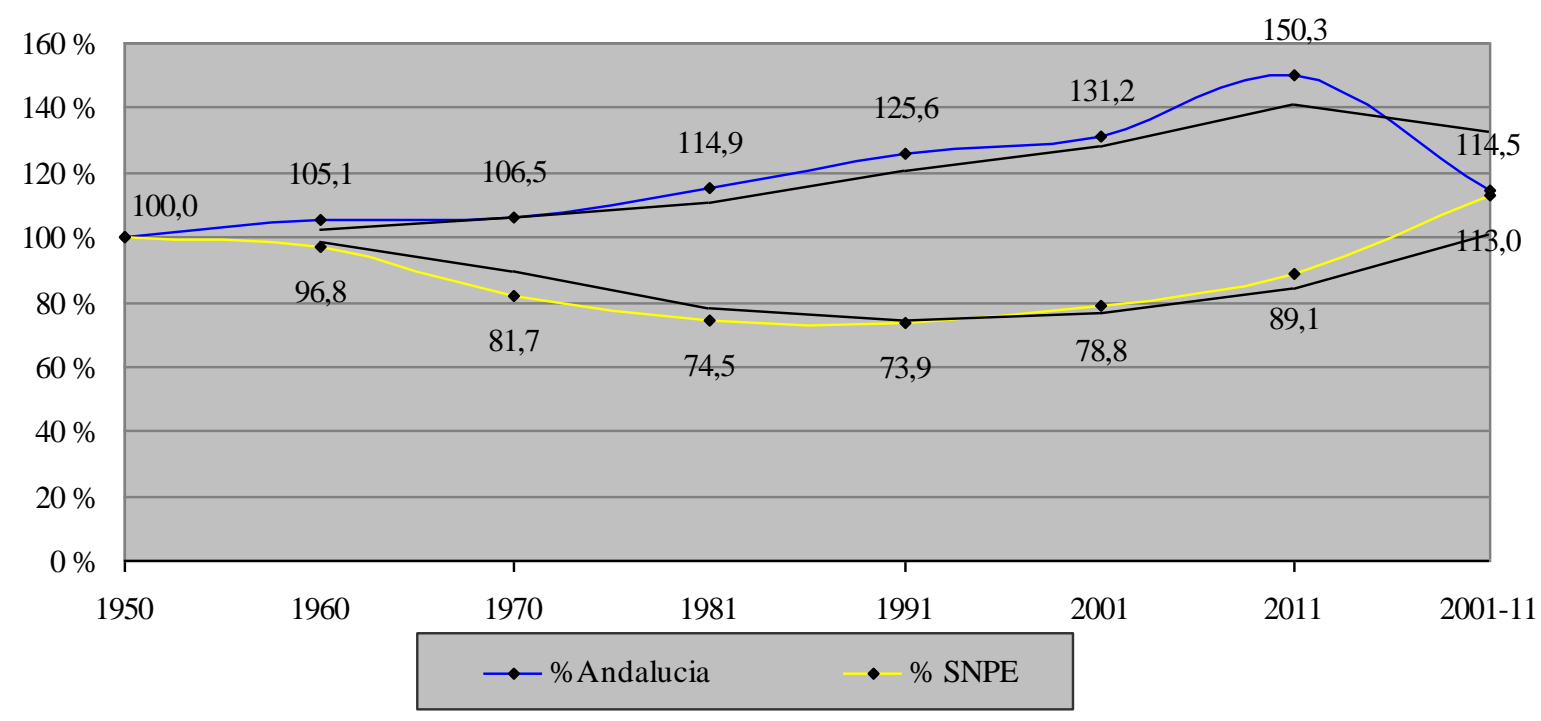

Fig 11. Population change in the Sierra Nevada protected space and in Andalusia, $1950-2011$ (1950 = 100). Source: www.ine.es.

The proximity to the urban area not only allowed SNPS municipalities to maintain their resident population, including young people, but also favoured in-migration in recent decades (Prados \& del Valle 2010). At the same time, municipalities located in the interior southern slope area of the SNPS, and therefore far from metropolitan influence, have benefited from policies on territorial rebalancing, such as improved access and the provision of basic health and education services, and have participated in rural development initiatives that promote nature tourism and environmental preservation (Figures, 12, 13 and 14). 

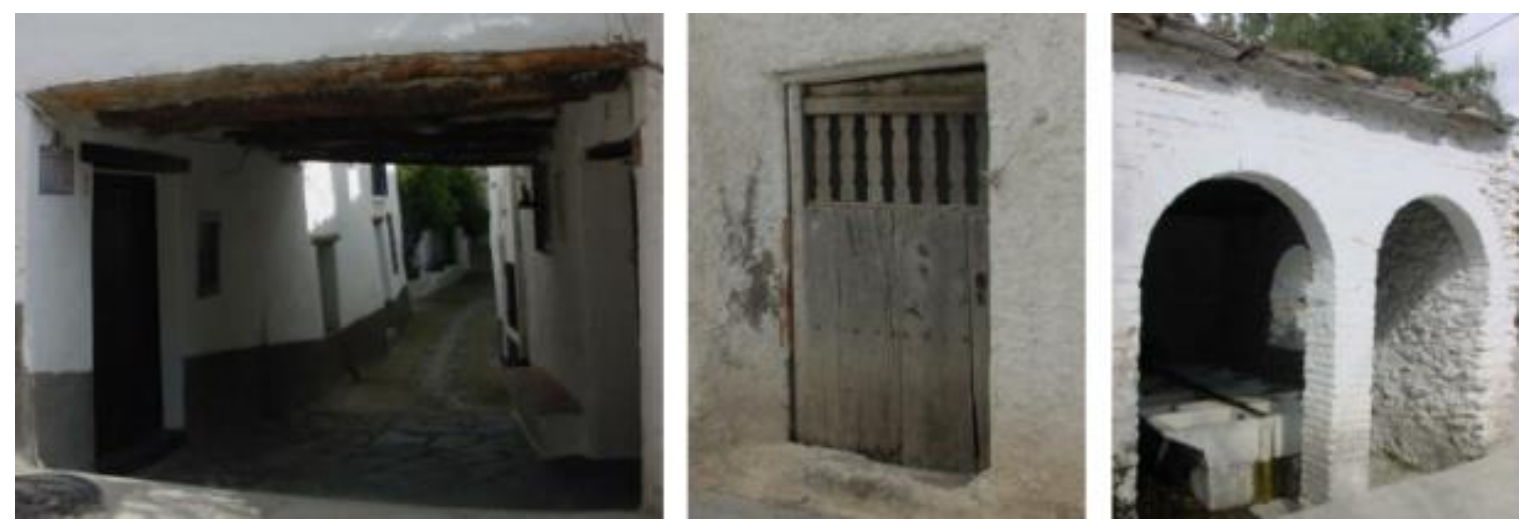

Fig 12, 13 and 14. Walkway (tinao), door, and laundry basins in Ferreirola (PNA Sierra Nevada). Authors: María José Prados.

Within this general context, several specific situations must be considered. Firstly, since 1991, some of these municipalities have experienced net migration gains much greater than the average for the Sierra Nevada as a whole. In "la Alpujarra", the zone located on the southern slope of the massif, in-migration that had been seasonal has begun to stabilize with the development of the tourism sector and the push for specialty agriculture. This county has also become the point of entry for Veleta Peak (3392 m) and the Sulayr route, which encircles the Sierra Nevada massif. Secondly, in-migration has increased in the counties of Alto Andarax and Nacimiento, northeast of the massif, more oriented toward the city of Almería than Granada. The third zone that has gained population is in the county west of the massif, on "Guadix" slope just east of the Granada urban area, the primary source of "naturbanites" in that zone.

On the other hand, construction has not increased at the same pace as the population, and in some cases the built surface area increased as population continued to decline (Fig. 15).

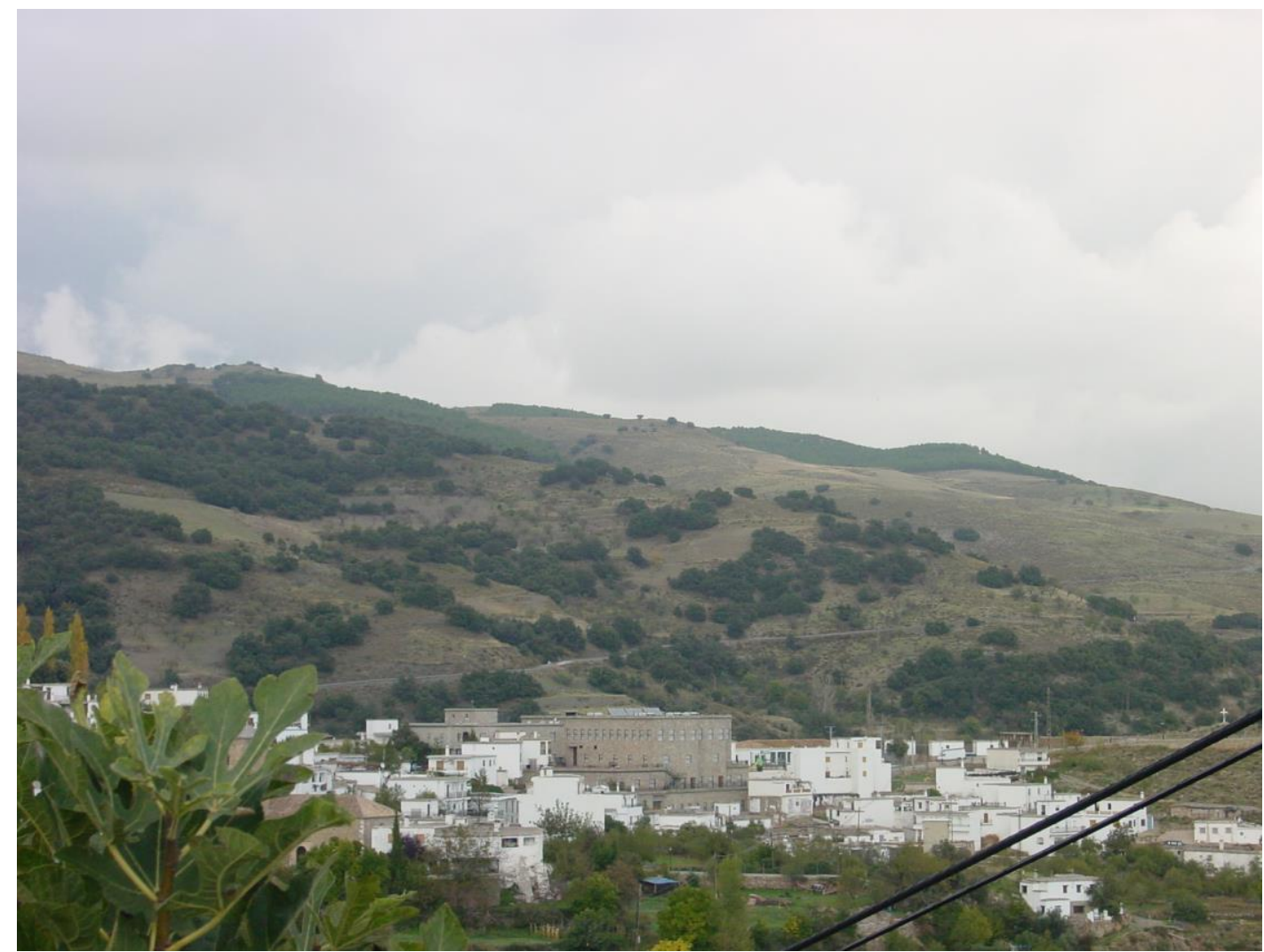

Fig 15. Nuevas construcciones (secadero de jamón) en Juviles. 
Figure 16 illustrates this imbalance in the case of Bubión municipality, where new construction has not been accompanied by population growth, which in fact continues to decrease. Between 1950 and 1980 the built surface area increased 2.42 hectares, while the population went from 828 to 353 residents. Between 1980 and 1999 the situation stabilized but beginning in 2000 the built surface area increased at a rate of 0.16 hectare/year until 2004 , or 0.70 hectare overall, while the population decreased by 23 inhabitants.

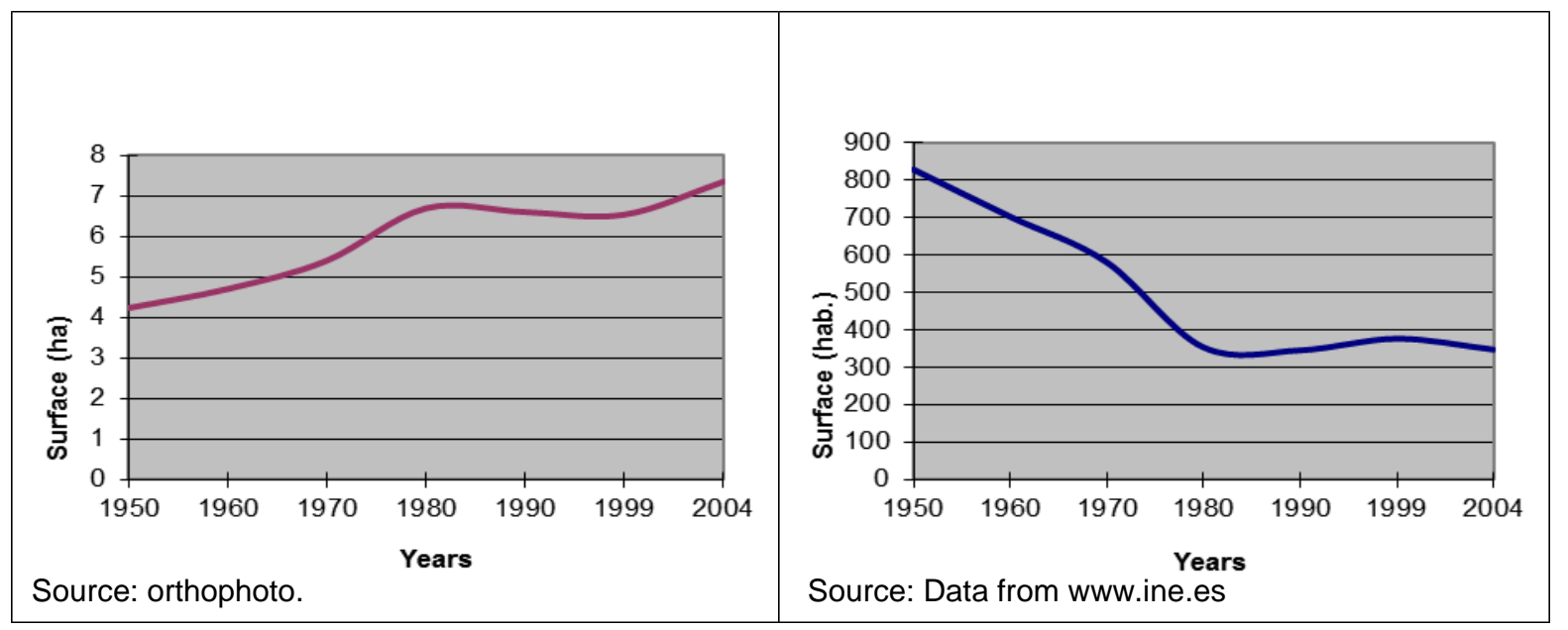

Fig 16. Changes in the built surface area and in total population in Bubión, 1950 - 2004.
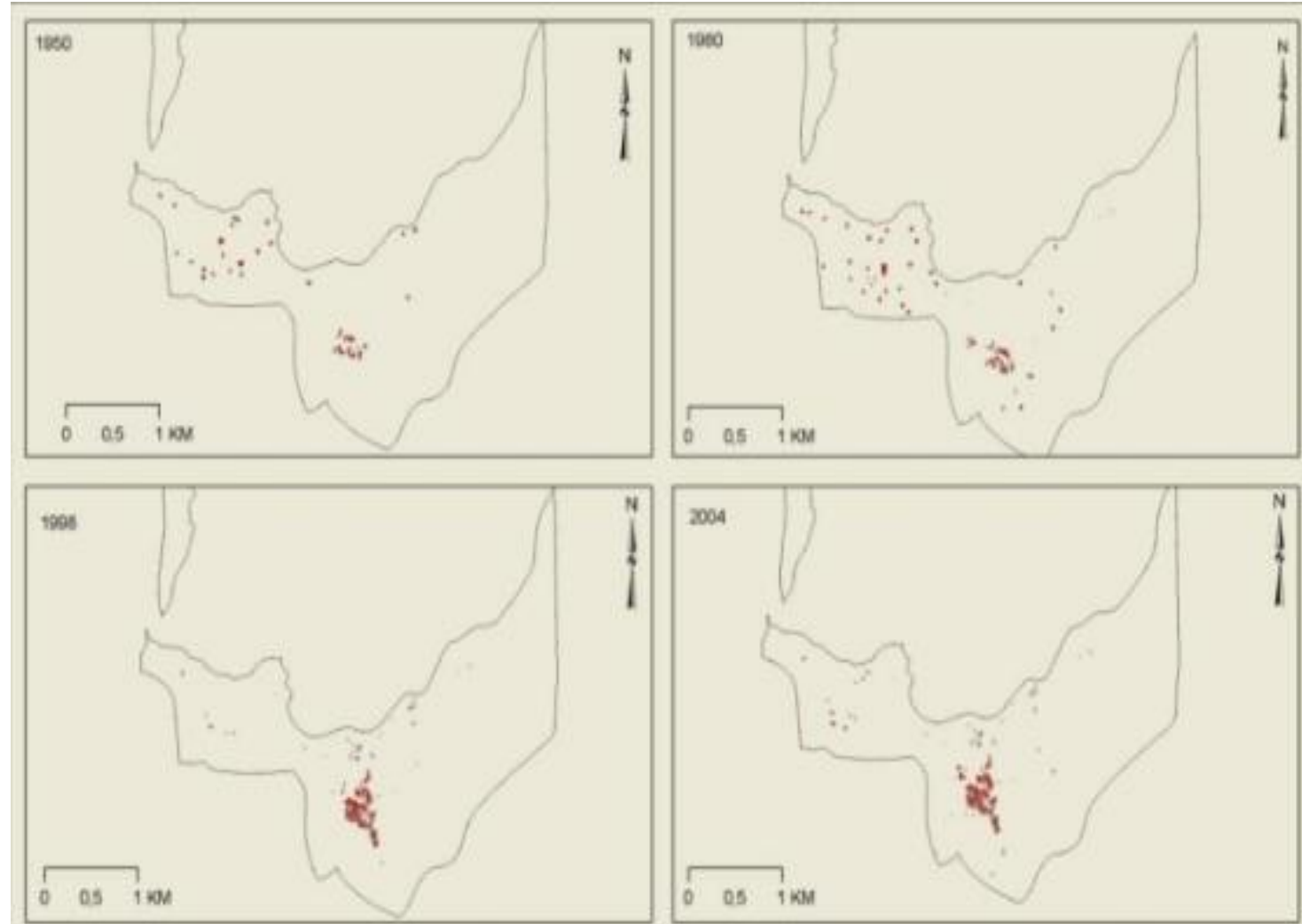

Fig 17. Changes in the built environment of Bubión, in Alpujarra County 1950-2004. Source: Self-developed from 1950, 1980, 1990 and 2004 orthophoto maps.

Table 2 shows that the percentage of non-principal dwellings inside the SNPS $(43.97 \%)$ is clearly higher than that of non-principal dwellings in external municipalities (34.84\%). Compared to 2001 data, there is an increase in non-principal dwellings to the detriment of principal 
residences, and a notably higher presence of second homes in the municipalities within the SNPS . $^{9}$

\begin{tabular}{|c|c|c|c|c|c|c|c|}
\hline Area & $\begin{array}{l}\text { Total, } \\
\text { family } \\
\text { dwellings }\end{array}$ & $\begin{array}{l}\text { Total } \\
\text { principal } \\
\text { dwellings } \\
\end{array}$ & $\begin{array}{l}\text { Total non- } \\
\text { principal } \\
\text { dwellings }\end{array}$ & $\begin{array}{l}\text { Principal } \\
\text { dwellings, } \\
\% \text { of total }\end{array}$ & $\begin{array}{l}\text { Non-principal } \\
\text { dwellings, \% of } \\
\text { total }\end{array}$ & $\begin{array}{l}\text { Total } \\
\text { second } \\
\text { homes }\end{array}$ & $\begin{array}{l}\text { Second } \\
\text { homes, \% } \\
\text { of total }\end{array}$ \\
\hline $\begin{array}{l}\text { Total, Provinces of Almeria } \\
\text { and Granada }\end{array}$ & 927,174 & 599,495 & 327,679 & 64.66 & 35.34 & $\ldots$ & $\ldots$ \\
\hline Municipalities inside SNPS & 876,654 & 571,188 & 305,466 & 65.16 & 34.84 & $\ldots$ & $\ldots$ \\
\hline Municipalities outside SNPS & 50,519 & 28,306 & 22,213 & 56.03 & 43.97 & $\ldots$ & $\ldots$ \\
\hline \multicolumn{8}{|c|}{2001} \\
\hline Area & $\begin{array}{l}\text { Total, } \\
\text { family } \\
\text { dwellings } \\
\end{array}$ & $\begin{array}{l}\text { Total } \\
\text { principal } \\
\text { dwellings } \\
\end{array}$ & $\begin{array}{l}\text { Total non- } \\
\text { principal } \\
\text { dwellings }\end{array}$ & $\begin{array}{l}\text { Principal } \\
\text { dwellings, } \\
\% \text { of total }\end{array}$ & $\begin{array}{l}\text { Non-principal } \\
\text { dwellings, \% of } \\
\text { total }\end{array}$ & $\begin{array}{l}\text { Total } \\
\text { second } \\
\text { homes }\end{array}$ & $\begin{array}{l}\text { Second } \\
\text { homes, \% } \\
\text { of total }\end{array}$ \\
\hline $\begin{array}{l}\text { Total, Provinces of Almeria } \\
\text { and Granada }\end{array}$ & 713,908 & 457,727 & 256,181 & 64.12 & 35.88 & 119,049 & 16.68 \\
\hline Municipalities inside SNPS & 673,456 & 433,090 & 240,366 & 64.31 & 35.69 & 110,841 & 16.46 \\
\hline Municipalities outside SNPS & 40,452 & 24,637 & 15,815 & 60.90 & 39.10 & 8,208 & 20.29 \\
\hline
\end{tabular}

Tab 2. Principal and non-principal dwellings by location, internal or external to SNPS, in 2001 and 2011. Source: 2001 and 2011 Household Census, Spain's National Institute of Statistics (Instituto Nacional de Estadística).

Other studies have demonstrated that the municipalities within the area of SNPS socioeconomic influence have had a more positive social and economic trajectory than other mountain zones of Andalusia with similar characteristics but no environmental protection initiatives (Fernández et al. 2009). The cited study reports diverse indicators of positive economic impact, in addition to the positive effects on demographic structure. The SNPS municipalities had an annual growth rate of $6.73 \%$ per person in net declared income $\left(\mathrm{IRPF}^{10}\right)$, compared with the $5.07 \%$ in other mountain areas of Andalusia and $4.50 \%$ in Andalusia overall (Fernández et al. 2009).

In fact, $72 \%$ of the business community reported a positive influence of the SNPS. The study indicates that $21.3 \%$ of disposable family income in the area was due to the PNA, which generated 7,650 jobs for the area (Fernández et al. 2009).

\subsection{The processes of naturbanization in Catalonia}

In this section we study the naturbanization process in the High Catalan Pyrenees (HCP), a remote area of Catalonia, which is in the north-east of Spain (Figure 18).

Aigüestortes i Estany de Sant Maurici is the only National Park in Catalonia, created in 1955 by the Spanish central government and administered by the government of the Autonomous Community of Catalonia since 1988. The park comprises a core area of 13,900 ha and a buffer zone of 26,079 ha. It is a wild mountain region in the Pyrenees, with peaks rising to $3,017 \mathrm{~m}$ and nearly 200 lakes, many of glacial origin. The park's elevation ranges from 1,600 to 3,000 metres and its valleys have differing orientations. For that reason it contains very different ecosystems. "Cadí-Moixeró Natural Park", created in 1984, encompasses 41,060 hectares in the south-eastern HCP region. It stretches for more than 30 kilometres over the mountain range of "Serra del Cadí and Moixeró" which is particularly impressive on the north face. Its highest point reaches 2,648 metres. High Pyrenees Natural Park, the largest natural park in Catalonia, is located just beside Aigüestortes i Estany de Sant Maurici National Park and covers an area of 69,850 hectares.

\footnotetext{
${ }^{9}$ Unfortunately, 2011 data are not available for second homes in municipalities with fewer than 2000 inhabitants. Instead, we had to use the data on non-principal dwellings; this category includes vacant dwellings.

${ }^{10}$ Personal income tax (Impuesto sobre la renta de las personas físicas).
} 


\section{Figure 18. Protected Matural Areas in High Catalan Pyrenees region, Catalonia}

\section{Protected Matural Areas}

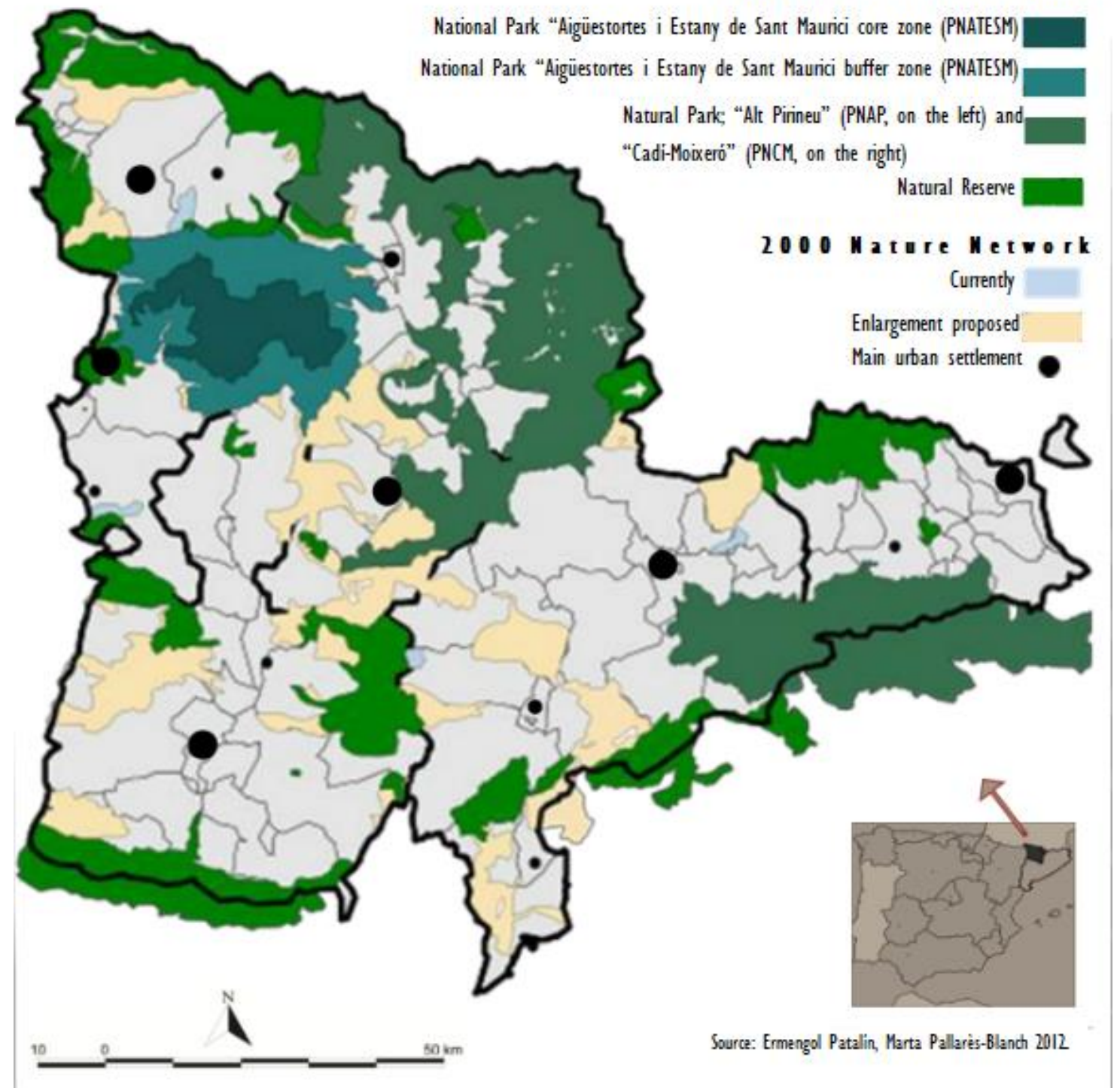

Fig 18. Protected Natural Areas in High Catalan Pyrenees region, Catalonia (Spain).

Almost half $(46.62 \%)$ of the HCP territory is under some type of environmental protection (Table 3), making this region a true nature preserve.

\begin{tabular}{|c|c|c|c|c|c|c|c|}
\hline Counties & $\begin{array}{l}\mathrm{Km}^{2} \\
\text { Total }\end{array}$ & \begin{tabular}{l|}
$\mathrm{Km}^{2}$ \\
Protected \\
Space
\end{tabular} & $\begin{array}{l}\% \\
\text { Protected } \\
\text { Space }\end{array}$ & $\begin{array}{l}\text { AESM }^{*} \\
\text { National } \\
\text { Park }\end{array}$ & $\begin{array}{l}\text { AP** } \\
\text { Natural } \\
\text { Park }\end{array}$ & $\begin{array}{l}\mathrm{CM}^{\star * \star *} \\
\text { Natural } \\
\text { Park }\end{array}$ & Others \\
\hline Alt Urgell & $1,447.50$ & 487.93 & 33.71 & & 104.85 & 123.14 & 259.94 \\
\hline Alta Ribagorça & 426.90 & 209.29 & 49.03 & 159.57 & & & 49.72 \\
\hline Cerdanya & 546.70 & 203.00 & 37.13 & & & 97.83 & 105.17 \\
\hline Pallars Jussà & $1,343.10$ & 462.23 & 34.41 & 58.82 & & & 403.41 \\
\hline Pallars Sobirà & $1,377.90$ & 956.85 & 69.44 & 212.86 & 698.87 & & 45.12 \\
\hline Val d'Aran & 633.60 & 373.53 & 58.95 & 62.54 & & & 310.98 \\
\hline Total HCP & $5,775.70$ & $2,692.83$ & 46.62 & 493.79 & 803.72 & 220.97 & $1,174.34$ \\
\hline
\end{tabular}

Tab 3. Protected Natural Areas in High Catalan Pyrenees (HCP) region by county and type, Catalonia (Spain). Source: Department of Territory and Sustainability. Natural Environment Area. 
The Autonomous Community of Catalonia is a densely populated territory in which the population distribution is highly imbalanced. The significantly less populated HCP region constitutes $18 \%$ of the Catalan territory but contains only $1 \%$ of the population of Catalonia, (Table 4). Therefore, this is a region of extreme conditions, abundant in natural resources and lacking in population. The primary reasons for the accelerated process of abandoning traditional activities during the second half of the 20th century and the resulting depopulation were the lack of services (highway and other communications, schools, electricity and water utilities, healthcare services network and sociocultural and health facilities) on one hand and on the other the absence of an endogenous model of development.

\begin{tabular}{|c|c|c|c|c|c|c|c|c|c|}
\hline \multirow{2}{*}{ COUNTY } & \multirow{2}{*}{$\mathrm{Km}^{2}$} & \multicolumn{4}{|c|}{ TOTAL POPULATION } & \multicolumn{3}{|c|}{ INDEX: $1950=100$} & \multirow{2}{*}{ 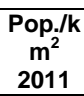 } \\
\hline & & 1950 & 1970 & 1991 & 2011 & 1970 & 1991 & 2011 & \\
\hline Alt Urgell & $1,447.5$ & 22,134 & 19,897 & 19,010 & 22,008 & 89.9 & 85.9 & 99.4 & 15.2 \\
\hline Alta Ribagorça & 426.9 & 5,296 & 4590 & 3,514 & 4,284 & 86.7 & 66.4 & 80.9 & 10.0 \\
\hline Cerdanya & 546.7 & 11,582 & 12465 & 12,396 & 18,783 & 107.6 & 107.0 & 162.2 & 34.4 \\
\hline Pallars Jussà & $1,343.1$ & 19,792 & 16,210 & 12,860 & 14,374 & 81.9 & 65.0 & 72.6 & 10.7 \\
\hline Pallars Sobirà & $1,377.9$ & 10,223 & 7,700 & 5,418 & 7,548 & 75.3 & 53.0 & 73.8 & 5.5 \\
\hline Val d'Aran & 633.6 & 6,555 & 5,055 & 6,184 & 10,192 & 77.1 & 94.3 & 155.5 & 16.1 \\
\hline Total HCP & $5,775.7$ & 75,582 & 65,917 & 59,382 & 77,189 & 87.2 & 78.6 & 102.1 & 13.4 \\
\hline Total Catalonia & $32,108.0$ & $3,240,313$ & $5,122,567$ & $6,059,494$ & $7,539,618$ & 158.1 & 187.0 & 232.7 & 234.8 \\
\hline$\% \mathrm{HCP} / \mathrm{Cat}$ & 18.0 & 2.3 & 1.3 & 1.0 & 1.0 & 55.2 & 42.0 & 43.9 & 5.7 \\
\hline
\end{tabular}

Tab 4. Population distribution by counties and demographic evolution in HCP (1950 - 2011). Index 1950. Sources: 1950, 1970: IDESCAT Sèries històriques and Centre for Demographic Studies (Centre d'Estudis Demogràfics) population data. 1991: IDESCAT Population Census. 2011: IDESCAT Municipal register of inhabitants. www.idescat.cat

The total HCP population in 2011 returned to the 1950 level, although there were major differences in distribution (Table 4). Only the Cerdanya, the county closest to Barcelona, achieved a nearly continuous rhythm of growth. Together with Val d'Aran, the other county with a tourism sector throughout the 20th century, population increased in absolute terms with respect to 1950. In Alt Urgell the population has remained constant after periods of loss. The three remaining counties --Alta Ribagorça, Pallars Jussà and Pallars Sobirà-- had less population in 2011 than in 1950 . In this context, we must remember the new ruralism phenomenon that began in the 1960s. In this urban-rural flow we find the origins of naturbanization; the motivation was not economic but rather a search for surroundings that are peaceful, freeing, less contaminated, and with a certain landscape quality that is valued by parts of the urban population, generally younger people. Indeed, "New ruralism expresses a profound change in territoriality, an essential transformation of an individual's relationships with his or her biosocial surroundings. This transformation manifests itself, basically, through a new conception of work, and of a whole series of new attitudes, behaviours and values in the most immediate surroundings" (Nogué, 1988: 167). The new ruralism ${ }^{11}$ movement was especially important in the Pyrenees, perhaps not in quantitative terms but wherever new ruralists settled they did end years of decline. They were the basis for the creation of new synergies that maintained the resident population of villages, slowed the rate of population aging, developed value-added activities, provided new information, produced a certain generational turnover, etc. We must also note that they arrived in advance of the trends toward mountain climbing, hiking, ski resorts, and organic agriculture (Soriano et al., 2003).

\footnotetext{
11 New ruralists (translated from neorural in Spanish and Catalan language) were considered a demographic phenomenon produced from the 1970 s to 1980 s, generated by the desire to live close to nature and to the rural past, representing a more sustainable way of life. They were basically young people coming from metropolitan areas and highly influenced by political movements like pacifism, communism and anarchism, and were strongly critical of capitalism and particularly of the Spanish dictatorship that persisted until 1977. This demographic movement, which has been compared with the 'beat generation' in USA, was significant in Spain, particularly in the Pyrenees. No quantitative data is available on the subject, but they are a reference for Spanish rural studies. A part from ideological motivations, the 'neorurals' decision to settle in more or less remote places was inspired by the idea of living this social model away from social pressure.
} 
After the 1960s, the major ski areas were established in the Pyrenees. However, not until Spain's construction boom began in the 1990s did the ski areas become a factor in promoting the construction of new second-home developments. The proportion of these homes progressively increased until they exceeded the number of principal residences in the most tourism-oriented counties, Cerdanya (53.6\% in 2011) and Val d'Aran (53.7 in 2011) (Table 5) ${ }^{12}$. They now appear to have reached market saturation since in both counties the proportion of second homes has decreased in respect with 2001 . For the region as a whole, second homes still exceed $40 \%$ of total housing units because this sector continues to increase in other counties, namely Alta Ribagorça, Pallars Jussà and Pallars Sobirà.

\begin{tabular}{|l|r|r|r|r|r|r|}
\hline & \multicolumn{1}{|c|}{$\begin{array}{c}\text { Second } \\
\text { homes } \\
2011\end{array}$} & $\begin{array}{c}\text { Total units } \\
2011\end{array}$ & $\begin{array}{c}\text { Second } \\
\text { homes/total } \\
(\%) 2011\end{array}$ & $\begin{array}{c}\text { Second } \\
\text { homes/total } \\
(\%) 2001\end{array}$ & $\begin{array}{c}\text { Second } \\
\text { homes/total } \\
(\%) 1991\end{array}$ & $\begin{array}{c}\text { Second } \\
\text { homes/total } \\
\text { (\%) } 1981\end{array}$ \\
\hline Alt Urgell & 2,640 & 14,138 & 18.7 & 19.7 & 11.8 & 13.2 \\
Alta & 1,881 & 4,323 & 43.5 & 34.8 & 29.5 & 14.8 \\
Ribagorça & 11,353 & 21,186 & 53.6 & 57.3 & 56.1 & 41.3 \\
Cerdanya & 3,786 & 10,966 & 34.5 & 27.0 & 24.4 & 25.8 \\
Pallars Jussà & 3,397 & 7,503 & 45.3 & 42.9 & 41.2 & 27.7 \\
Pallars & 5,446 & 10,133 & 53.7 & 56.0 & 64.7 & 54.0 \\
Sobirà & $\mathbf{2 8 , 5 0 2}$ & $\mathbf{6 8 , 2 4 8}$ & $\mathbf{4 1 . 8}$ & $\mathbf{4 1 . 1}$ & $\mathbf{3 8 . 7}$ & $\mathbf{3 0 . 4}$ \\
Val d'Aran & & & &
\end{tabular}

Tab 5. Second homes compared to total housing. HCP and Counties, 1981 - 2011. Source: IDESCAT, from Population and household Census, National Statistical Institute, Spain (INE).

This development model has given rise to two territorial dynamics and consequently to two very different types of landscape. On one hand, urbanization has been concentrated and intensified in new residential areas or in expansions of existing communities. Sometimes this new urbanization is located in mountain valleys near cities that attract the most tourism. In many cases this has reconfigured the original urban character of the affected towns as new construction predominates over the old (Figure 19). Developers have often introduced architectural styles from other European mountain regions, displacing local styles. In these cases, the basic natural element of the territory is notably diminished as the artificiality of the space increases. As a consequence, the landscape loses symbolic value as a natural and traditional space (Bertrand \& Bertrand, 2002).

\footnotetext{
12 The distinction between second homes in use and vacant non-principal dwellings is available for all municipalities in the Catalan case study. The number of vacant non-principal dwellings in the HCP is quite limited: $8,684(12.7 \%$ of total dwellings). Even so, the data on second homes in the Catalan case are more precise than those in the case from Andalusia because the latter include vacant dwellings.
} 


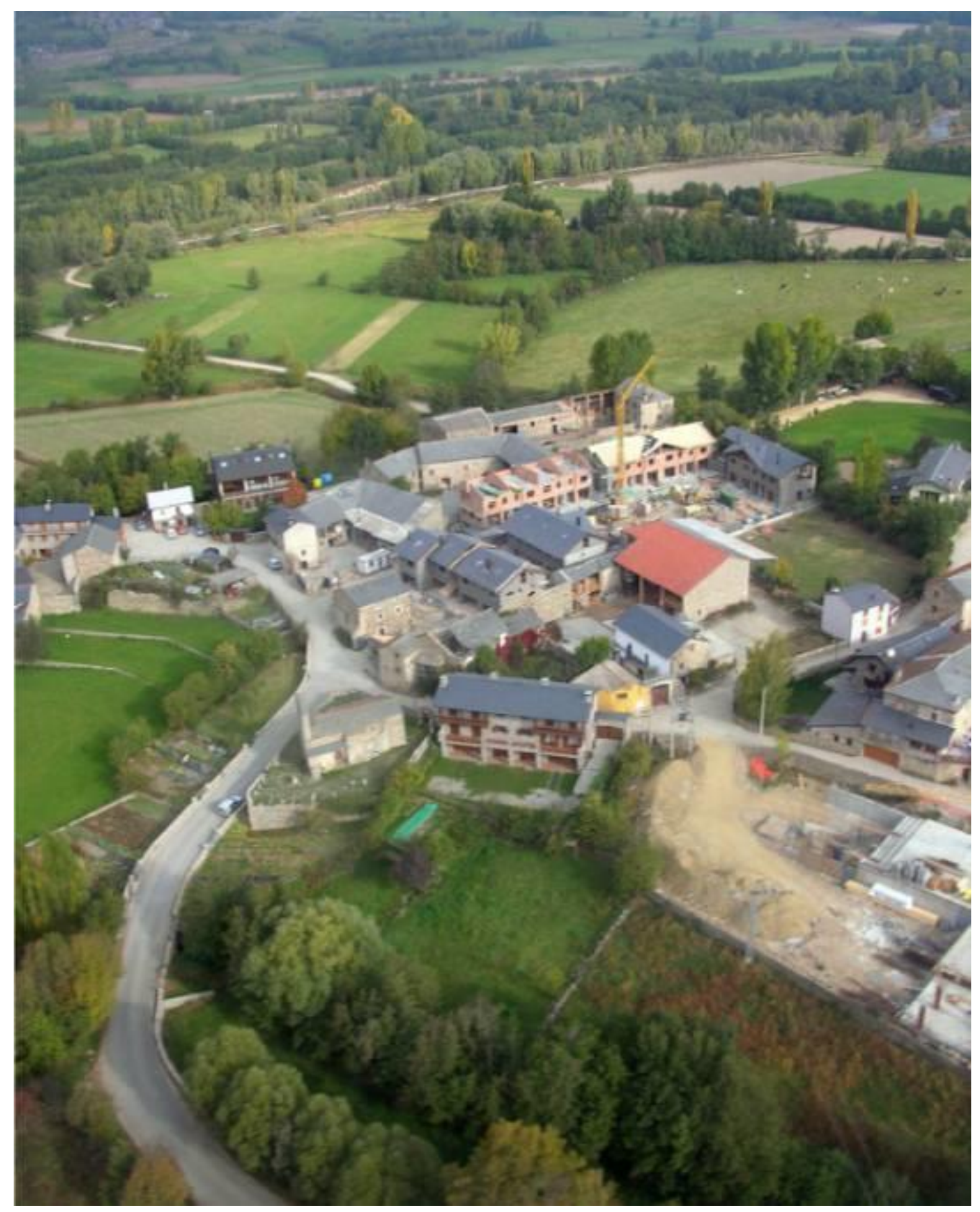

Fig 19. Naturbanization has an impact on Cerdanya County. Author: Marta Pallarès-Blanch. 


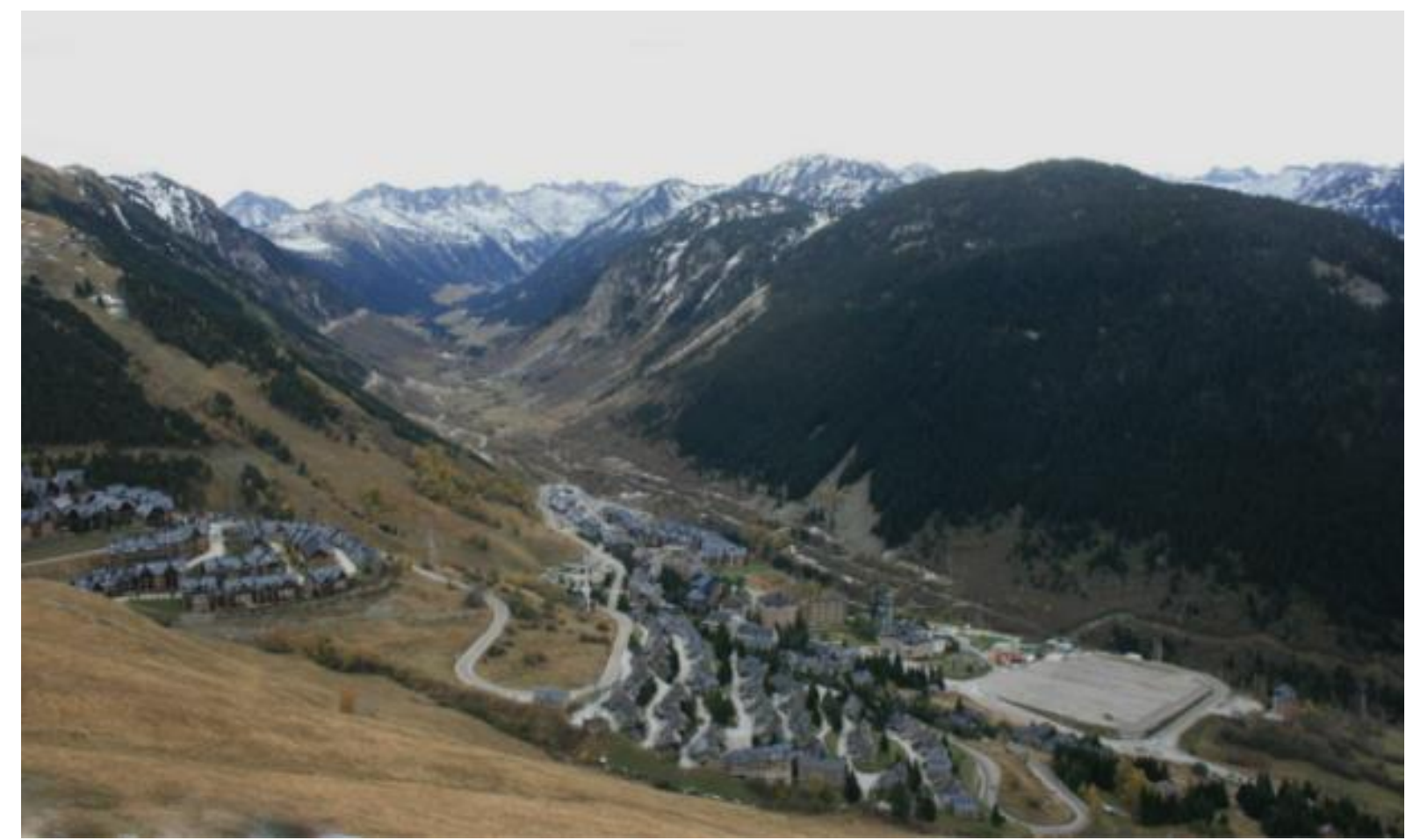

Fig 20. Townhouses on the slope of the Vall de Ruda, Val d'Aran County, HCP, 2011. Author: Albert Pèlachs.

In other cases, new urbanization is found in the highest mountain areas, next to ski areas and always close to a major PNA (Figure 20). In terms of landscape, the predominant orthogonal urban morphology (townhouses) imposes a standardized urban ethos that is unrelated to the traditional village morphology and the pre-existing urban hierarchy if there had been one. In the absence of an existing urban space, the new townhouses are localized as residential enclaves with no urban configuration (Figure 21). In any case, the increase in urbanized surface area for residential and seasonal use has occurred mostly at the margins of the territorial functionality of these spaces.

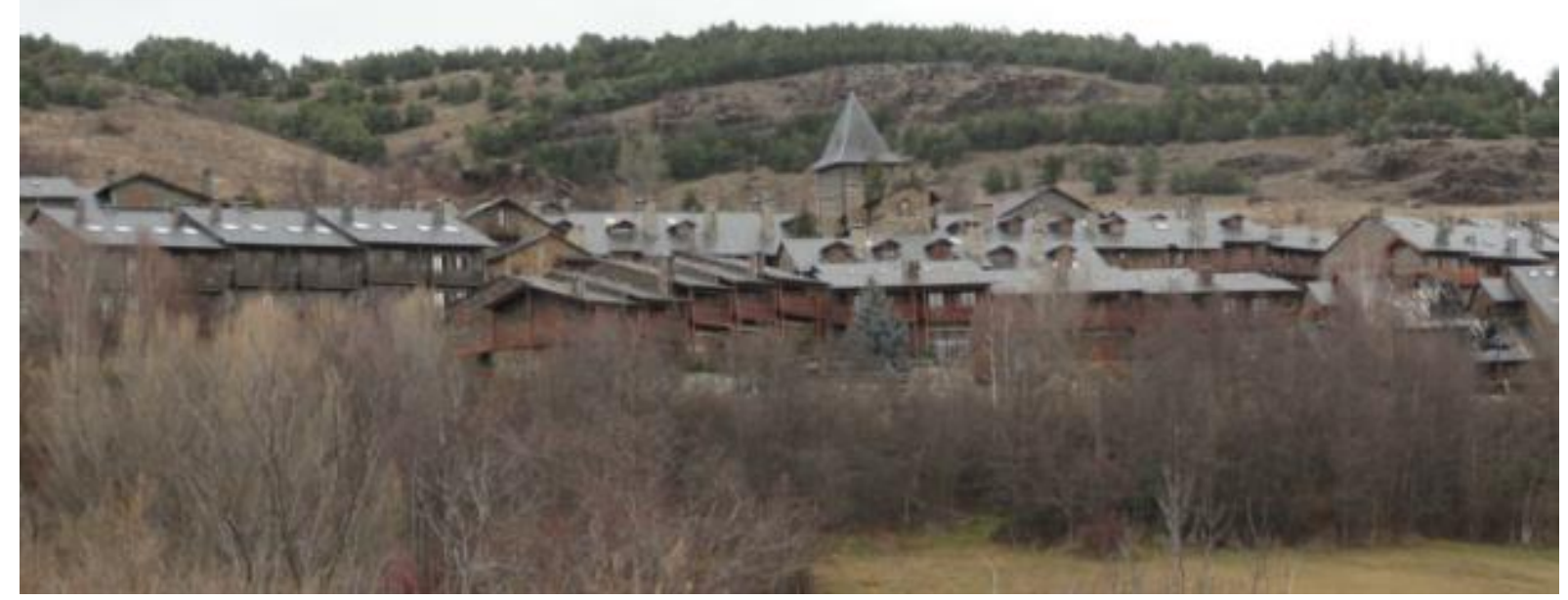

Fig 21. Urbanization between two municipalities, Ger and Bolvir, Cerdanya County, HCP. Author: Antoni F. Tulla.

On the other hand, in high mountain areas where tourism and real estate development have not yet arrived, small villages continue to be in the process of abandonment (Figure 22), except in areas that have attracted new permanent residents (Figure 23). 


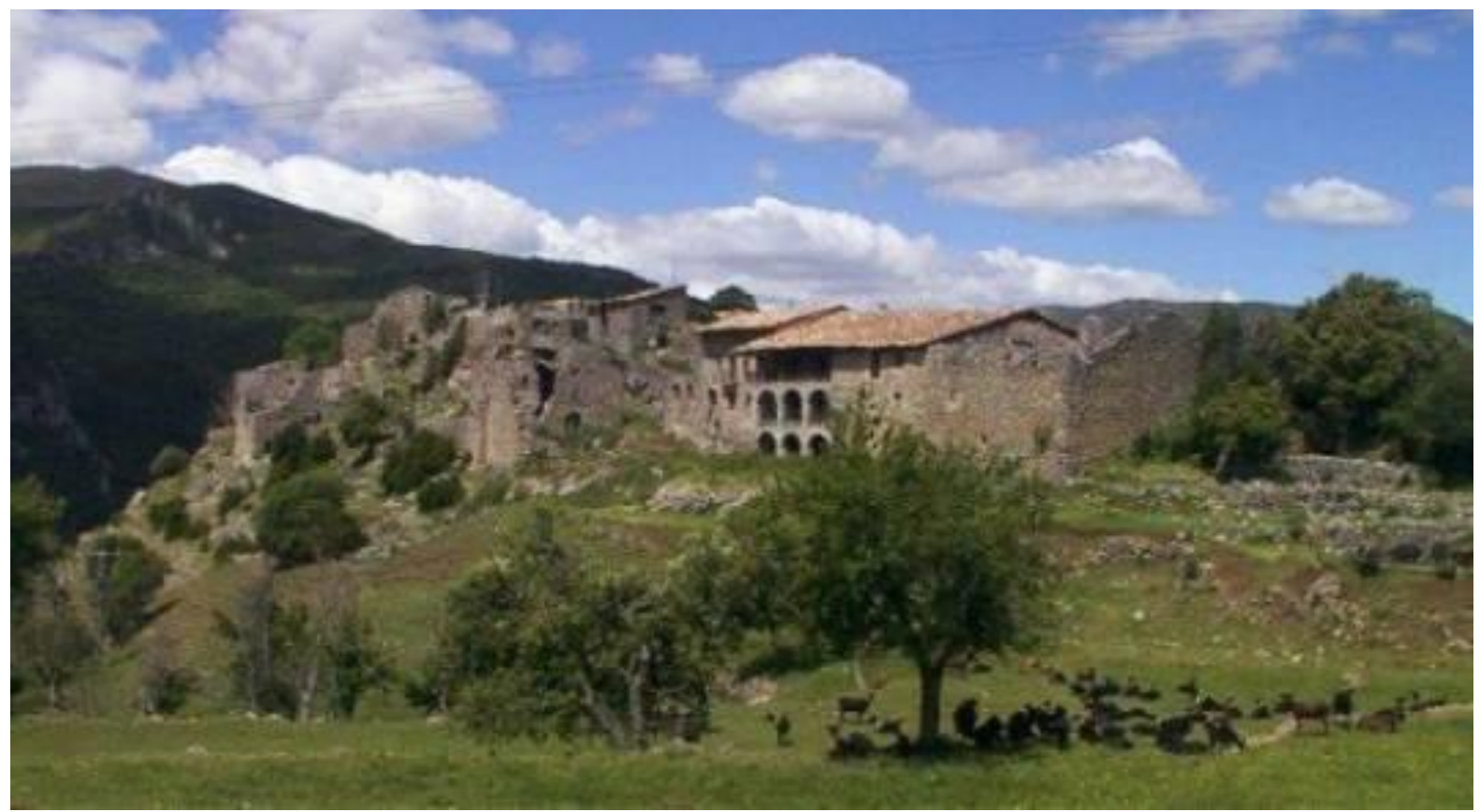

Fig 22. Puigcerver, a semi-abandoned village in the HCP, 2004. Author: Marta Pallarès-Blanch.

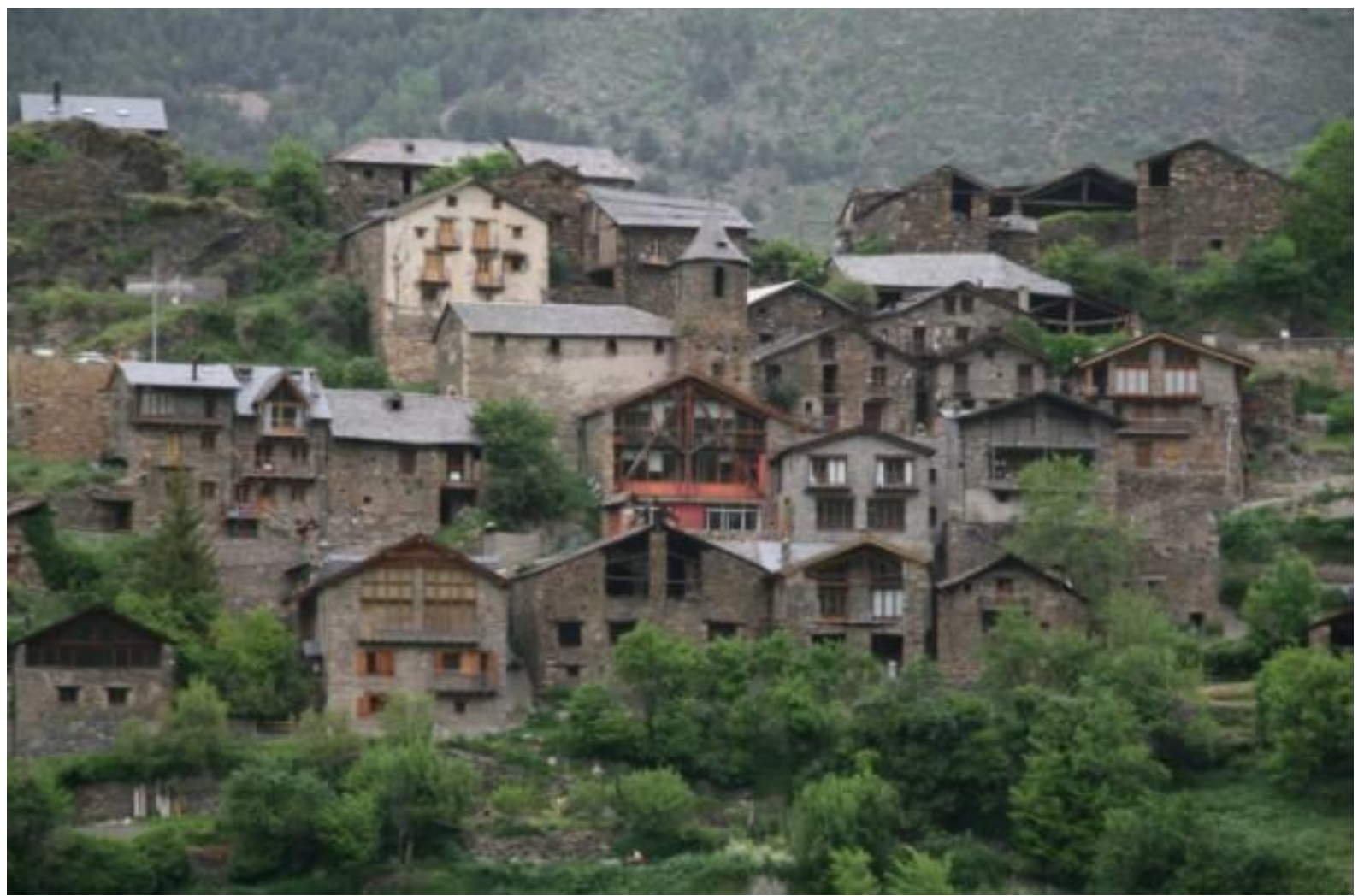

Fig 23. Farrera de Pallars (Burg, Pallars Sobirà, HCP). Example of a village sustained by new ruralists and new services related to the High Pyrenees Natural Park. Author: Albert Pèlachs.

Despite the landscape impact and major internal imbalances, we must acknowledge that this model of territorial development has inverted the regressive dynamic that previously existed. Beginning in the 1990s, the region's population grew steadily until 1999 (Figure 24). A population boom began early in the next decade that was sustained, with some oscillations in the growth curve, until the beginning of the current economic crisis. Total population growth clearly corresponds directly with in-migration flows that neutralize the negative natural growth rate. 


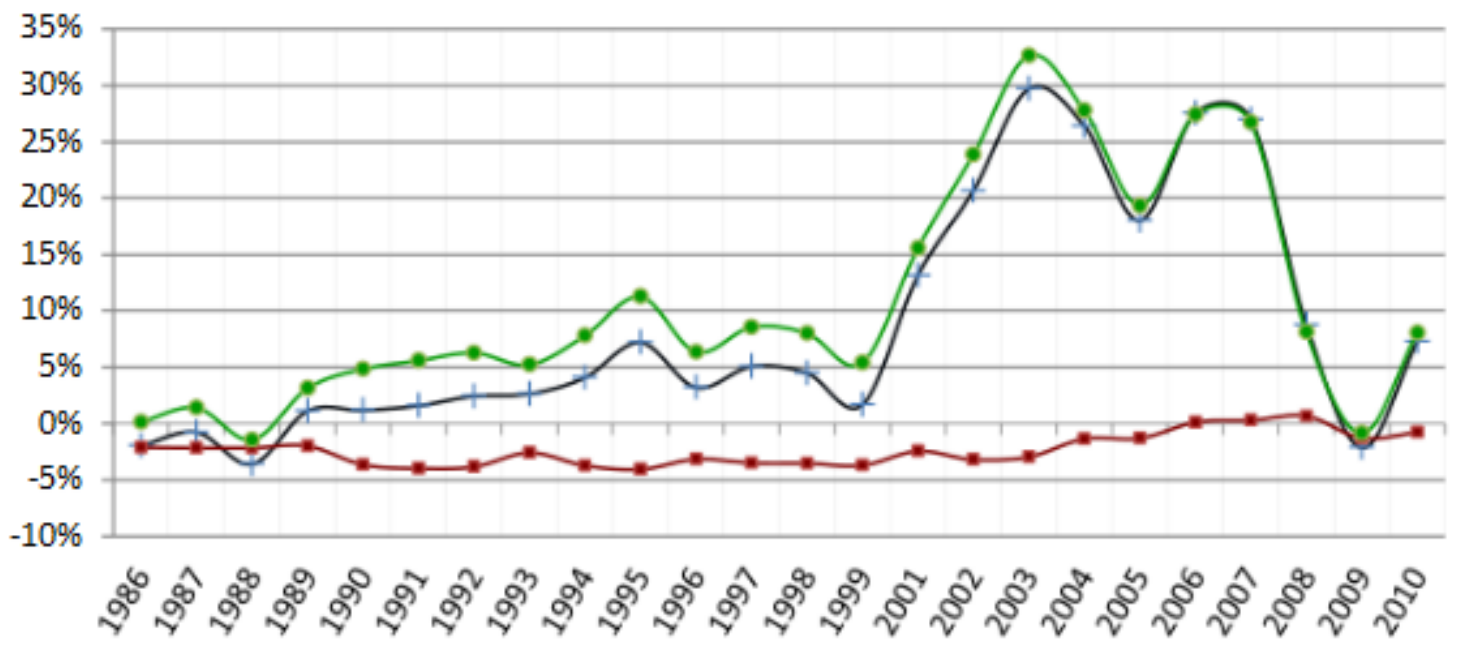

$\longrightarrow$ Total $\rightarrow$ Natural $\rightarrow$ Migratory

Fig 24. Total, Natural and Migratory Growth of the HCP population (1986 - 2010). Source: Self-development using IDESCAT data (1986 - 2010).

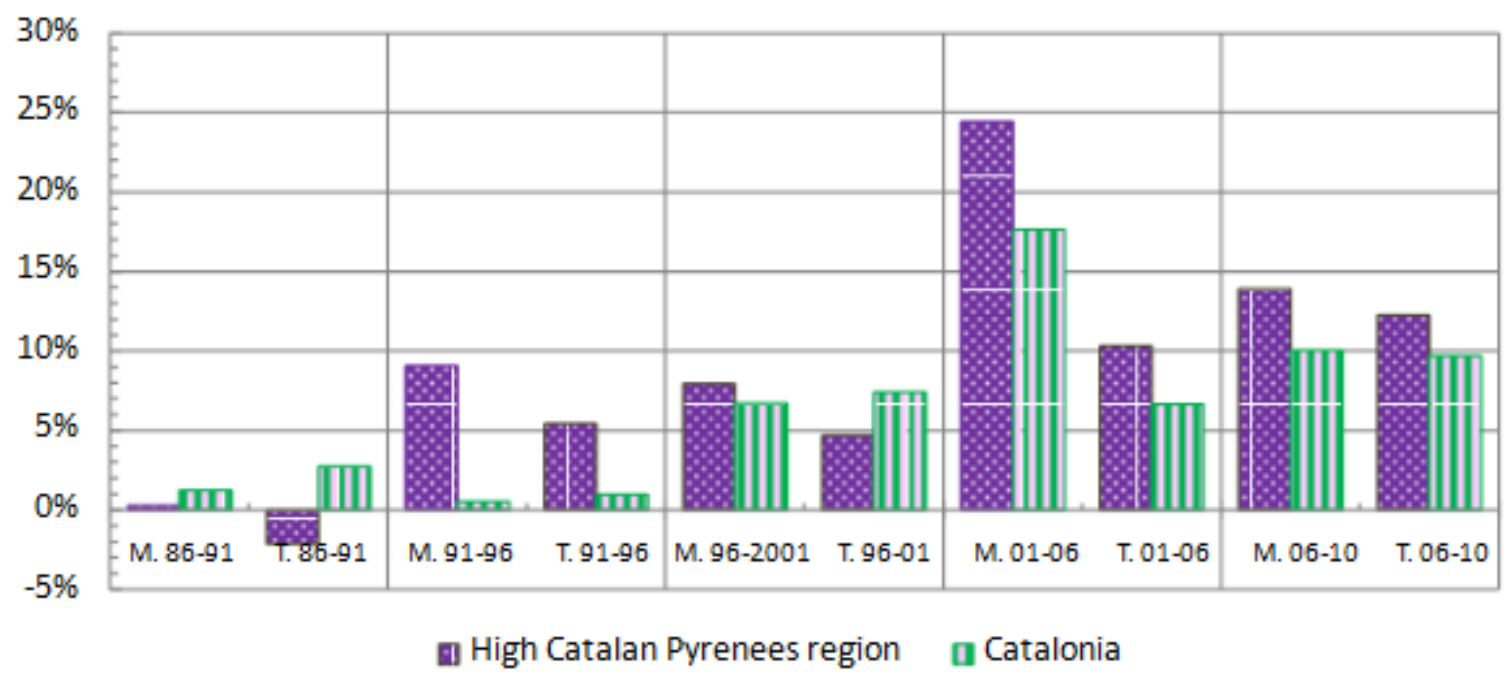

Source:IDESCAT data (1986-2011)

Fig 25. Migratory and Total Population Growth. HCP \& Catalonia (1986 - 2011).

As a region, Catalonia has received a high impact of immigration, a powerful current phenomenon in Spain. We must remember that Spain is the natural gateway to Europe for Spanish-speaking Latin American immigration and much of the recent African immigration. Since 1997, no EU country has exceeded Spain in annual net migration. In 2010 , $13 \%$ of the Spanish population was foreign-born and this migration was concentrated in the areas with the highest levels of economic activity and tourism: the coastal northeast and east-central part of the country and Madrid. In the two cases at hand, the rate of immigration was $7.1 \%$ in Andalusia in 2008 and 13.5\% Catalonia for the same year (Castro \& Mora, 2011). Therefore, we cannot attribute this change in the demographic model exclusively to naturbanization because in-migration has had an extraordinary impact in Catalonia over the past decade (Figure 25). 


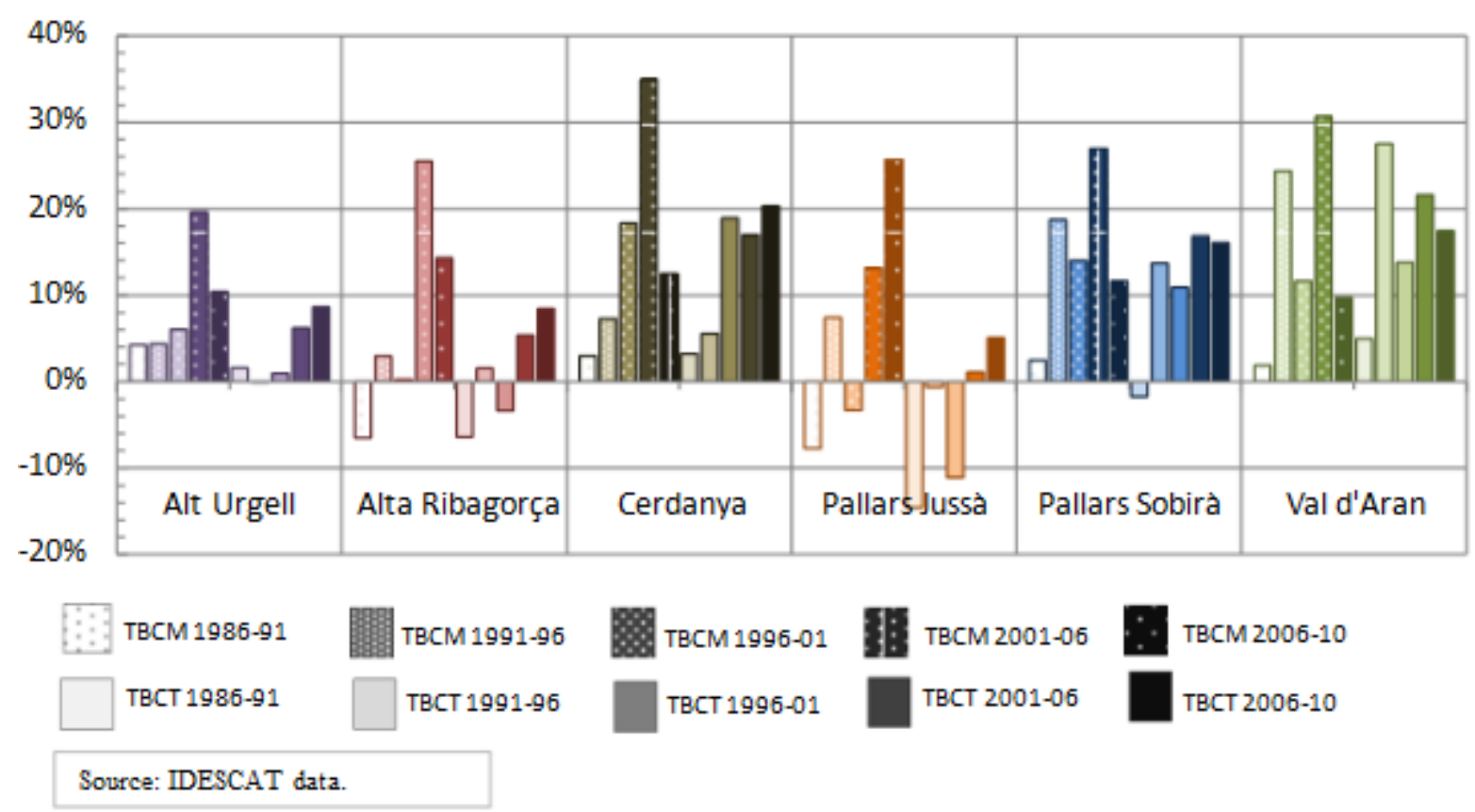

Fig 26. Migration growth. High Catalan Pyrenees counties, 1986 - 2010.

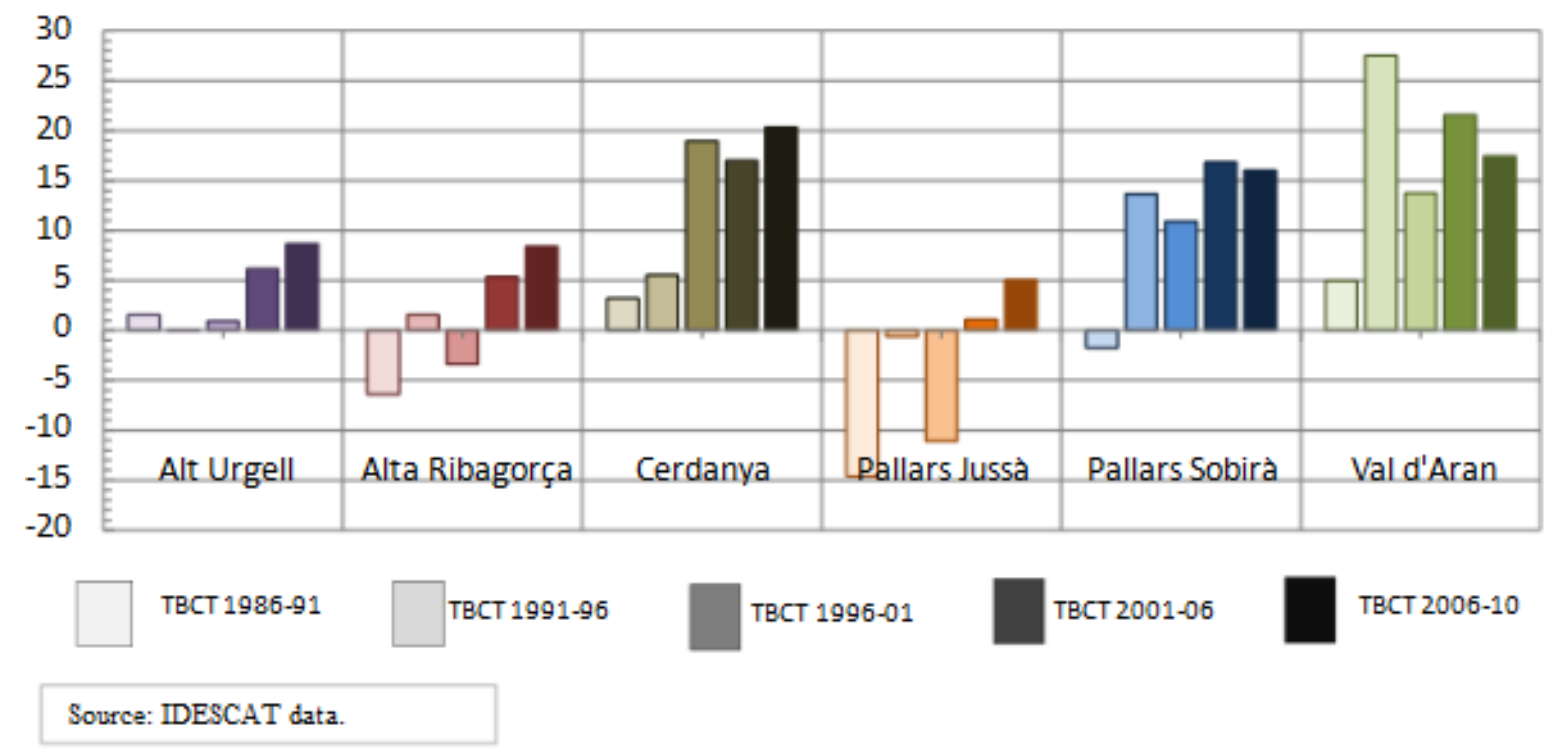

Fig 27. Total growth. High Catalan Pyrenees counties, 1986 - 2010.

At the county level, we observed two patterns of demographic growth: rapid growth in Cerdanya, Pallars Sobirà and Val d'Aran and scant growth in Alt Urgell, Alta Ribagorça and Pallars Jussà (Figure 26 and Figure 27).

The greatest population growth between 1991 and 2011 occurred in the counties with the most tourism, which also have the largest spaces designated as PNA (Tulla \& Pallarès-Blanch, 2008).

Two key indicators are needed to identify and measure processes of naturbanization in the HCP region: the ratio of principal residences to total housing (Table 6) and the ratio of second homes compared to total housing (Table 7) and the number of full-time inhabitants per day and year (Tables 8).

Second homes have had --and continue to have-- great weight in the HCP region housing. In 2011, these constituted $41.8 \%$ of the region's residences (Table 5). In the two most touristoriented of the six counties, Cerdanya and Val d'Aran, second homes predominated over principal residences, $53.6 \%$ and $53.7 \%$, respectively. In the HCP region, second homes 
continued to increase in the 2001-2011 decade, at the rate of $33.7 \%$, although this was a major slowdown compared to the 51.3\% growth in 1981-1991 and slightly higher than $31.2 \%$ in 1991 2001 (Table 6). At the county level, there are two significant data points. On the one hand, Val d'Aran $(23.4 \%)$ and Cerdanya $(25.0 \%)$ had rates similar to Alt Urgell $(23.2 \%)$, where second homes have traditionally been of little significance. The low growth rates of second homes in these two counties indicate the saturation of this market. On the other hand, the areas of highest growth - $-110.4 \%$ in Alta Ribagorça, 55.6\% in Pallars Sobirà and $45.7 \%$ in Pallars Jussà- show that these areas have not yet exhausted their period of second home expansion.

\begin{tabular}{|l|r|r|r|r|r|r|r|}
\hline \multirow{2}{*}{ County } & \multicolumn{4}{|c|}{ Second Homes } & \multicolumn{3}{c|}{$\begin{array}{c}\text { Growth in Second vs } \\
\text { Total (\%) }\end{array}$} \\
\cline { 2 - 8 } & \multicolumn{1}{|c|}{1981} & \multicolumn{1}{|c}{1991} & 2001 & 2011 & $\mathbf{8 1 - 9 1}$ & $\mathbf{9 1 - 0 1}$ & $\mathbf{0 1 - 1 1}$ \\
\hline Alt Urgell & 1,093 & 1,094 & 2,143 & 2,640 & $\mathbf{0 . 1}$ & $\mathbf{9 5 . 9}$ & $\mathbf{2 3 . 2}$ \\
Alta Ribagorça & 247 & 648 & 894 & 1,881 & $\mathbf{1 6 2 . 3}$ & $\mathbf{3 7 . 9}$ & $\mathbf{1 1 0 . 4}$ \\
Cerdanya & 3,692 & 6,776 & 9,081 & 11,353 & $\mathbf{8 3 . 5}$ & $\mathbf{3 4 . 0}$ & $\mathbf{2 5 . 0}$ \\
Pallars Jussà & 1,96 & 1,946 & 2,598 & 3,786 & $\mathbf{- 7 . 0}$ & $\mathbf{3 3 . 5}$ & $\mathbf{4 5 . 7}$ \\
Pallars Sobirà & 1,065 & 1,797 & 2,182 & 3,397 & $\mathbf{6 8 . 7}$ & $\mathbf{2 1 . 4}$ & $\mathbf{5 5 . 6}$ \\
Val d'Aran & 2,676 & 3,980 & 4,411 & 5,446 & $\mathbf{4 8 . 7}$ & $\mathbf{1 0 . 8}$ & $\mathbf{2 3 . 4}$ \\
\hline TOTAL HCP & 10,733 & 16,241 & 21,31 & 28,502 & $\mathbf{5 1 . 3}$ & $\mathbf{3 1 . 2}$ & $\mathbf{3 3 . 7}$ \\
\hline
\end{tabular}

Note: Growth of t period, f.i. 2011, in relation to t-1 period f.i. 2001 , is calculated in this way, $[(\mathrm{t}-(\mathrm{t}-1)) \times 100]: \mathrm{t}-1$.

Data Source: Household Census, 1981, 1991, 2001 and 2011 Spain's National Institute of Statistics (Instituto Nacional de Estadística).

Tab 6. Proportion of Second Homes in the HCP, 1981 - 2011.

\begin{tabular}{|l|r|r|r|r|r|r|r|}
\hline \multirow{2}{*}{ County } & \multicolumn{4}{|c|}{ Principal residences } & \multicolumn{3}{c|}{$\begin{array}{c}\text { Growth in Primary } \\
\text { vs Total (\%) }\end{array}$} \\
\cline { 2 - 8 } & \multicolumn{1}{|c|}{1981} & 1991 & 2001 & 2011 & $\mathbf{8 1 - 9 1}$ & $\mathbf{9 1 - 0 1}$ & $\mathbf{0 1 - 1 1}$ \\
\hline Alt Urgell & 5,413 & 6,190 & 7,017 & 8,794 & $\mathbf{1 4 . 3}$ & $\mathbf{1 3 . 4}$ & $\mathbf{2 5 . 3}$ \\
Alta Ribagorça & 1,128 & 1,124 & 1,367 & 1,810 & $\mathbf{- 3 . 0}$ & $\mathbf{2 1 . 6}$ & $\mathbf{3 2 . 4}$ \\
Cerdanya & 3,498 & 4,050 & 5,543 & 7,665 & $\mathbf{1 5 . 8}$ & $\mathbf{3 6 . 9}$ & $\mathbf{3 8 . 2}$ \\
Pallars Jussà & 4,419 & 4,480 & 4,753 & 5,639 & $\mathbf{1 . 4}$ & $\mathbf{6 . 1}$ & $\mathbf{1 8 . 6}$ \\
Pallars Sobirà & 1,603 & 1,796 & 2,486 & 3,183 & $\mathbf{1 2 . 0}$ & $\mathbf{3 8 . 4}$ & $\mathbf{2 8 . 0}$ \\
Val d'Aran & 1,607 & 1,893 & 2,848 & 3,973 & $\mathbf{1 7 . 8}$ & $\mathbf{5 0 . 4}$ & $\mathbf{3 9 . 5}$ \\
\hline TOTAL HCP & 17,668 & 19,533 & 24,01 & 31,064 & $\mathbf{1 0 . 6}$ & $\mathbf{2 2 . 9}$ & $\mathbf{2 9 . 3}$ \\
\hline
\end{tabular}

Note: Growth of t period, f.i. 2011 , in relation to $t-1$ period f.i. 2001 , is calculated in this way, [(t- (t-1)) $\times 100]: \mathrm{t}-1$.

Data Source: Household Census, 1981, 1991, 2001, 2011 Spain's National Institute of Statistics (Instituto Nacional de Estadística).

Tab 7. Proportion of Principal Residences in the HCP, 1981-2011.

With respect to principal residences, there is notable growth, ranging from $10.6 \%$ in 1991 to $22.9 \%$ in 2001 and $29.3 \%$ in 2011 (Table 7), although less than the increase in second homes. In this case, the growth distribution by county is the inverse of the second homes trend. The counties with the least growth in principal residences are Pallars Jussà (18.6\%) and Alt Urgell (25.3\%). The counties in which the growth of the secondary sector slowed the most are those that reported the greatest growth in principal residences: Val d'Aran (39.5\%), Cerdanya (38.2\%).

From 1981 to 2001, there was a major increase in seasonal residents, shown by the growth in second homes (Table 6). In the following decade, there was a significant increase in principal residences -- surpassing that of second homes. Although we cannot assert with any confidence that some part of the seasonal population became permanent residents, it seems certain that the increase in second homes was accompanied by an increase in principal residences. 
To determine the population burden of the HCP region, we have access to data on inhabitants/day, an indicator that reflects the estimated seasonal population, which differs from the official census. In general terms, inhabitants/day includes five components: 1) Principal residences (population residing in the town); 2) Second homes (population staying in their own or others' houses or visiting family and friends), 3) Tourism (overnight stays in tourist establishments); 4) Labour mobility (no overnight stays); and 5) Mobility studies (other purposes, no overnight stays). The most recent estimates of actual population indicate an overall decline between 1991 and 2010, even in the counties with the most tourism (Table 8). Therefore, due to slower growth in second homes in 2010 there was a lower estimate of seasonal population. Nonetheless, the HCP has a higher percentage of seasonal population than is calculated for Catalonia as a whole.

\begin{tabular}{|c|c|c|c|c|c|c|c|c|c|}
\hline County & $\begin{array}{l}\text { Estimated } \\
\text { Pop. } 1991\end{array}$ & \begin{tabular}{|l|} 
Pop. \\
Census \\
1991 \\
\end{tabular} & $\begin{array}{l}\text { Inh./day } \\
1991\end{array}$ & \begin{tabular}{|l|} 
Estimated \\
Pop. \\
2001 \\
\end{tabular} & \begin{tabular}{|l|} 
Pop. \\
Census \\
2001 \\
\end{tabular} & $\begin{array}{l}\text { Inh./day } \\
2001\end{array}$ & \begin{tabular}{|l|} 
Estimated \\
Pop. \\
2010 \\
\end{tabular} & \begin{tabular}{|l|} 
Pop. \\
Census \\
2010 \\
\end{tabular} & $\begin{array}{l}\text { Inh./day } \\
2010\end{array}$ \\
\hline Alt Urgell & 23,029 & 19,010 & 1.21 & 27,185 & 19,349 & 1.40 & 23,374 & 22,005 & 1.06 \\
\hline Alta Ribagorça & 5,140 & 3,514 & 1.46 & 7,144 & 3,623 & 1.97 & 5,360 & 4,278 & 1.25 \\
\hline Cerdanya & 24,771 & 12,396 & 2.00 & 41,897 & 14,239 & 2.94 & 24,675 & 18,549 & 1.33 \\
\hline Pallars Jussà & 16,872 & 12,860 & 1.31 & 19,342 & 12,817 & 1.51 & 15,038 & 13,978 & 1.08 \\
\hline Pallars Sobirà & 10,681 & 5,418 & 1.97 & 17,337 & 6,120 & 2.83 & 9,644 & 7,646 & 1.26 \\
\hline Val d'Aran & 20,689 & 6,184 & 3.35 & 28,972 & 7,956 & 3.64 & 12,807 & 10,206 & 1.25 \\
\hline Total HCP & 101,182 & 59,382 & 1.70 & 141,877 & 64,104 & 2.21 & 90,898 & 76,662 & 1.19 \\
\hline Catalonia & $6,340,255$ & $6,059,494$ & 1.05 & $6,988,973$ & $6,331,231$ & 1.10 & $7,618,631$ & $7,512,381$ & 1.01 \\
\hline$\%$ HCP/Cat. & 1.60 & 0.98 & 162.85 & 2.03 & 1.01 & 200.49 & 1.19 & 1.02 & 116.92 \\
\hline
\end{tabular}

Tab 8. Inhabitants per day and year. HCP Counties and Catalonia, 1991 - 2010. Data Sources: Mendizábal (1993) for Estimated Population 1991 and 2001 and Catalan Institute of Statistics (IDESCAT) for the 2010 estimate of seasonal population.

In summary, the HCP experienced a regressive scenario after the 1950 s and lasting until the 1980s, with the abandonment of agricultural and other traditional activities. After the 1980s there was intensive development of second homes, generally near the ski areas located in counties that had been summer destinations throughout the 20th century because of their natural attractiveness. As a consequence, there was an increase in seasonal population (number of inhabitants per day) between 1991 and 2001 in every county in the region, exceeding the average of Catalonia as a whole. On the other hand, between 2001 and 2010 this indicator decreased to values below those of 1991, although remaining above the overall average for Catalonia. This leads us to consider the establishment of a territorial development model that generates new permanent residences. The high in-migration rate that began in 2000 (Figure 27) was generalized throughout Catalonia. Nonetheless, the HCP region acquired a larger contingent due to the job opportunities, primarily in the construction sector and secondly in the hospitality sector (restaurants, hotels, etc.), followed by expansion of the service sector.

\section{Naturbanization and the new rural landscape in Andalusia and Catalonia}

Both areas studied; rural natural areas in Sierra Nevada -SNPS- (Andalusia) and rural natural areas in the HCP (Catalonia) seem to have shared in the population recovery during the past decade, after decades of decline. Although natural population growth remains stagnant or declining in certain areas, most generally the migration processes in both zones have been inverted. Demographic recovery thanks to in-migration is their common factor. The greater inmigration trend has occurred in the HPC, which reflects the high influx of newcomers to Catalonia during the past decade. In previous decades, both areas exported population as a consequence of the recession in traditional agriculture, the lack of job opportunities and the difficulty of achieving a quality of life similar to that of cities. Nonetheless, a few decades later agriculture had become specialized and production was focussed on high-quality, value- 
added food items. At the same time, villages reached a level of services that arrived "better late than never", but in some cases after a majority of the local population had emigrated.

Urbanization in open spaces has been a growing process of great importance in Spain in the past 30 years. In the HCP region of Catalonia, this urbanization has basically consisted of constructing residential areas in attractive landscapes, or as close as possible if urbanization of the surrounding area is restricted. To a great extent, these areas are concentrated around ski stations, which in turn are close to a region's major PNAs. This has implied the occupation of parts of the territory by second homes, with the resulting increase in seasonal population. Second homes expansion in HCP was in part due to the influence of the Barcelona Metropolitan Area (2012 population: $\left.3,239,337^{13}\right)$, the largest potential critical mass in Catalonia, even though it is 150 to $300 \mathrm{~km}$ from the study area. On the other hand, the Granada metropolitan area (2011 population: $519,510^{14}$ ) in Andalusia is closer to the SNPS, which favours naturbanization. In both cases, the zones close to the PNA had a higher percentage of nonprincipal residences in 2011 than the rest of their communities $(41.8 \%$ in HPC and $44 \%$ in SNPS, compared to $12.2 \%$ in Catalonia and $14.4 \%$ in Andalusia) or Spain as a whole $\left(14.6 \%{ }^{15}\right)$.

The second homes model of development has promoted the growth of tourist services that have yielded undeniably positive results in mountain areas (Ganau, 2013). These are reflected in the rise of per capita income in areas formerly affected by abandonment of agrarian activities and, consequently, scarred by depopulation. Gross Disposable Income per capita in 2000 was 12,900 Euros in HCP (11,800 Euros in Catalonia) and 18,000 in 2008 (16,900 in Catalonia) ${ }^{16}$. However, this model of development alters the balance between economic activities and those elements that produce a culturally and socially attractive landscape. Therefore, landscape preservation in mountain areas, as we have inherited it from the 20th century, is not guaranteed without the maintenance of agrarian activities (Soriano et al., 2003).

Over the past two decades, public institutions in these remote and natural areas, together with the private sector, have promoted the tourism trademarks. In the HCP, the Pyrenees trademark is tightly linked to snow sports but also goes beyond the winter season by incorporating rural tourism, mountain climbing, hiking, trekking, horseback riding, etc. During this period, the small primary sector became professionalized and new economic activities with higher added value were initiated, such as cooperatives producing dairy products that merit quality seals of approval and products with the protected designation of origin, or geographical indication of quality designation (Tulla et al., 2009). Local identities have been strengthened, in part, thanks to the development of artisan food products and arts and crafts workshops (Alamon et al., 2012). Using local resources, these facilities produce foods, decorative arts, and crafts that complement the tourist offerings and provide a link to the primary sector. In the case of the SNPS, these new activities are based on efforts to establish highly diversified tourism activities, the reactivation of crop and livestock operations, and the transformation of local products to high-quality, value-added offerings (Tolón \& Lastra, 2009a). To a great extent, the image of the SNPS is emblematic of environmental and landscape quality that places value on the territory. This PNA holds European Charter of Sustainable Tourism status ${ }^{17}$ since 2003 , and has a long history of combining tourism with value-added activities in the natural and socioeconomic arenas (Gessa \& Toledano 2011).

The government of Andalusia played a major role in the establishment of synergies between tourism and sustainable rural development in economically depressed rural zones, most of

\footnotetext{
${ }^{13}$ Source: Catalan Statistics Office.

${ }^{14}$ Source: Andalucia Statistics Office. Official population data from the 1 January 2012 update of the municipal register.

${ }^{15}$ Source: 2011 Household Census, Spain's National Institute of Statistics (Instituto Nacional de Estadística).

${ }^{16}$ Source: Catalan Statistics Office

17 The European Charter of Sustainable Tourism incorporates the European and worldwide priorities stated in the recommendations of Agenda 21, adopted during the Rio Earth Summit in 1992, and by the 5th programme of community actions for sustainable development. CETS favours the definite application of the concept of sustainable development. Local parties involved in some way in the tourism industry draw up a common strategic plan for the future every five years and put into practice its proposals.
} 
which were located in natural parks. Although they had different effects in the various territories where they were applied, there were numerous specific legislative initiatives (among them, the Programmes for the Integrated Development of Rural Tourism in Andalusia, 1987 and 1992; General Plan for Tourism in Andalusia, 2000-2006; and the Senda Plan, 2000 - 2004). These initiatives were in response to the different needs of the territories, according to the strategies outlined such as favouring a type of tourism that differed from that of the coastal areas, complementing tourism development with preservation of natural and cultural heritage, creating and improving tourist accommodations, introducing technological and organizational innovations, participating in international tourist circuits, training and retraining employees in the sector, coordinating environmental protection with tourism promotion, etc. (Flores \& Barroso 2012). The importance of the territories in the analysis and development of these policies was also studied. The Andalusia model of rural development is associated with the existence and strength of non-profit associations, called rural development groups that were established within the EU LEADER framework and adopted as part of executing the Plan for Andalusia Rural Development and Programme for Economic Development and Diversification in Rural Zones (de Pablo \& Berino 2002).

In the case of the Catalan government, a reasonably effective management of mountain areas was achieved, as evidenced by the High Mountains Law (Llei 2/1983) and policies implemented by the Generalitat de Catalunya in the 30 years since. Two examples that can be cited are the agreement that created the Plan for General Mountain Policy and the Interdepartmental Mountain Group in 2002 (part of the Department of Territorial Policy and Public Works) and the establishment of the Institute for the Development and Promotion of the High Pyrenees and Aràn in 2002 (Ganau, 2013). In the HCP, the partial territorial plan (Pla territorial parcial de l'Alt Pirineu $i{A r a n^{18}}^{1}$ ) is the region's principal tool for organizing the territory, and pays special attention to the PNA. Grants are available to fund projects that support the preservation, improvement and promotion of the PNAs in four ways: 1) management of the natural heritage, 2) development of infrastructure related to public uses, 3) improvement of structures for agricultural or livestock uses, and 4) dissemination of environmental values and of heritage.

The framework of EU rural development programmes is particularly important, specifically the LEADER programmes and others at the state and regional level that offer useful tools to transfer methods for planning rural development strategies to the local scale. This includes adopting (to a greater or lesser extent) a bottom-up approach. These tools have also provided the basis for incorporating mechanisms to encourage participation and cooperation, in some cases making possible major steps forward in local governance (Esparcia 2000). This is especially important if local communities are to regulate naturbanization (Mehnen et. al. 2009).

Indeed, multifunctionality and sustainable development concepts owe their origins, at least in part, to debates within the policy community about rural development. Consequently, perspectives are starting to shift away from a sectorial compensation ethos towards an increasing recognition of the wider opportunities available to rural areas (Copus \& Dax 2010). In a certain manner, the European Union's rural development programmes have been directed at facilitating the professionalization, expansion or generation of businesses of the same type as those initiated by new ruralism pioneers at the end of the 1970s and that were based on the use of local and/or agrarian resources. Activities devoted to agrarian diversification such as rural tourism and the production of high-quality food products have been particularly supported by the LEADER programme, along with other Rural Development Programme initiatives by which governments encourage innovations in agriculture. Projects that reintroduce extinct species, interconnect natural spaces, create means of environmental communication or establish heritage-related facilities are examples of the type of initiatives that have been supported by the LIFE programme and by FEOGA and FEDER funding. These funds are transferred to the regions and administered in specific ways (New Sources of Employment

\footnotetext{
${ }^{18}$ Catalan law $(24 / 2001,31$ December), establishes thematic content for partial territorial plans that is similar to the general plan: a) Definition of nuclei that are especially appropriate for facilities of interest to the county; b) Designation of spaces of natural interest; c) Definition of agricultural or forestry land uses of special interest; d) Infrastructure placement; e) Areas protected from construction and natural spaces of historical-artistic interest; f) Socioeconomic development planning; and g) Urban planning.
} 
Programme, Pilot- and Experimental Projects, Local Development Facilitators, etc.). Other programmes that should be mentioned include cooperation between border territories (INTERREG), which encourages connections and networking between organizations, institutions, etc., including Natural and National Parks. All of these activities contribute to the preservation and recognition of the values of landscape and of natural and cultural heritage, and favour the establishment of businesses that promote sustainable rural and local development. All of this has helped to retain local residents and attract returning natives or newcomers, with the help of the increasing mobilization and communication among people, including telework (Pallarès-Barberà 2004; Tulla et. al., 2009; Halfacree 2012; Solé et al. 2012).

For all the elements examined in the case studies, we identify one sector of the in-migrant population whose residential mobility is not exclusively related to economic considerations, although these are indirectly relevant. Within this sector of new residents, nature is a key element in their decision making, whether for personal enjoyment or as a work-related factor.

Where the permanent population increases, naturbanization contributes to sustainable local development and reduces the dichotomy between the interests of visitors and inhabitants (Figueiredo, 2009). The new model combines landscape preservation with the introduction of new value-added activities, often generated by the new residents, thereby respecting the balance between anthropised natural elements and new needs for urban space (Tulla et al., 2009). To some extent, the two models, real estate promotion of second homes and sustainable rural development, have proceeded in parallel in some areas, even though they have evolved at different rhythms and are located in different parts of the territory. The promotion of second homes tends to occur outside or adjacent to existing population centres, while new permanent residents are more likely to renovate homes or abandoned buildings, normally located within the rural population centre. The demographic and economic recovery reflected in the data undoubtedly is produced by the first model, which is more exogenous --and particularly so in the HCP region. It would not be fair to ignore the more sustainable model initiated by the new ruralists that has become the backbone of sustainable local development in these communities. New ruralists in-migration began in the 1970s, when the PNAs were practically non-existent as a social factor and some of them had not yet been established (Corraliza et al. 2002). Without a doubt, however, we can identify sensitivity toward natural preservation and rural ways of life as a factor in the choice of place of residence for these new "rural settlers". Similarly, in other qualitative studies based on study area the presence of a high-quality natural environment is a determining factor in the population that has arrived or returned to areas with a PNA (Solé et al., 2012; Guirado, 2011).

According to the growth charts, population growth is totally dependent on in-migration. However, the economic crisis may prove to be a factor in population trends. At the end of the real estate bubble in 2008, the more exogenous model also came to an end. There are now some indications that the lack of jobs in rural areas, which is now more acute, is slowing the inmigration trend. Nonetheless, there is evidence that urban unemployment causes some sectors of the population, especially those with family ties to rural areas, to plan a personal and employment future in these newly revalued zones (Domínguez García et al. 2012). In any case, the foundation exists to compare the results of both models, the one based on second homes promotion and the other based on integrated rural development principles. This is the dilemma faced by PNAs. These spaces offer added value, now that after decades of abandonment they can entice residents, present opportunities for development, and therefore reactivate some villages that would otherwise have been condemned to extinction. Naturbanization can help to break the vicious circle of population decline and loss of services in peripheral rural areas (Sedlacek et al. 2009). The laws that protect these spaces were not achieved without confronting opposition from local economic sectors (Troitiño et al. 2005). Therefore, the processes of naturbanization can provide evidence of contradictions in our system but also, at the same time, offer new perspectives and new development opportunities in territories where it had seemed for decades that nothing could occur. 


\section{Conclusions and Recommendations}

One of the most significant expressions of rural revaluation is reflected by PNAs with particular landscape qualities, such as National Parks and Natural Parks, attracting not only visitors but also permanent or seasonal residents nearby or within their boundaries if possible. This sociodemographic phenomenon, and its effects on rural space, was studied in this paper using the concept of naturbanization, which is based upon urban-rural spatial dynamics theories, namely the field of counter-urbanization. However, while counter-urbanization stands for urban demographic deconcentration patterns, naturbanization includes the pull factor of rural natural areas attracting newcomers. Amenity migration studies have also assessed the influence of environmental elements on residential mobility. Despite their different theoretical traditions, both lines of research reveal the great importance of rural natural areas, often governed by conservation measures, in contemporary spatial transformations. Naturbanization arises in the $21^{\text {st }}$ century as a consequence of the spread of environmental values and the increasing quality of life in rural areas -and public provision of infrastructure - that allows the assimilation of many aspects of an urban life style. The importance of natural values in studies of residential mobility in rural areas is observed across Europe, including Mediterranean countries like Spain, where the blurring of rural-urban distinctions occurred later than in Northern European countries.

Naturbanization processes have been analysed in this paper by comparing two PNAs in mountain areas of Spain, one in Andalusia, in the south, and the other in Catalonia, in the northeast. In both areas, territorial units (municipalities in Andalusia and counties in Catalonia) located in or close to the PNA experienced greater population growth than those more distant from the PNA. In both cases, net migration flows occur in areas with a history of demographic decline. This is, according to naturbanization studies, the first sign of a naturbanization process. Housing expansion, as the second indicator, is also present in both areas. It is particularly important to observe that growth in second homes is greater and constitutes a higher percentage of total residences in zones close to PNAs than in the rest of the mountains of the study areas. The difference between the two case studies was the earlier arrival of the second home phenomenon in the Pyrenees, where the growth had slowed in the most recent study period; in contrast, the later growth in second homes in the SNPS showed a higher recent rate of growth. The third indicator in the naturbanization process is the positive impact on sustainable local development of the new residents attracted by natural values. The EU's rural development policies have had a major impact on the economic diversification of rural territories, especially in the most remote areas where local resources, especially landscape and heritage aspects, have a decisive role in the emergence of territorial development processes. However, the results do not seem to have the same degree of implementation in all areas. In both case studies, there were examples of best practice in sustainable rural development initiatives due to local products of distinctive quality and the channels for proximity product commercialization. The study results show the positive influence of the PNAs in socioeconomic dynamics, generating neo-endogenous processes of territorial development, although this was more evident in the case of Andalusia. The evidence of this is their European Charter of Sustainable Tourism status, a distinction that has not been achieved by the Catalan parks in the study area. As shown by the present study, where tourist amenities are less present, local assets are the added value. The results suggest that a lower level of private investment can be not only worthwhile but can represent greater opportunity to implement public policies promoting sustainable rural development.

The threats of a more mature or even saturated urbanization process, particularly significant in the Catalan case, affect the conservation of natural landscape because naturbanization has major impacts on the landscape. In order to implement naturbanization phenomena in a more sustainable model of local rural development, it is essential to include the attraction of new residents as a key element in PNA management plans. In this sense, it is important to emphasize the need to strengthen the crucial role of PNA managers in remote areas, so that they can provide leadership or at least coordinate development programmes that are compatible with protecting ecological, economic and social balance. This policy should be accompanied by support for the creation of businesses related to artisan food products and 
environmental tourism. On the other hand, it is crucial that land uses in the protected space be controlled by measures that organize a network of small cities and towns or villages with a hierarchical transportation system that improves access and regional connectivity. Secondly, this structure must consider all PNAs, in accordance with the Nature 2000 Network. Thirdly, both the agrarian and industrial areas must be protected from the extensive urbanization of the territory, respecting the European Landscape Agreement (Florence 2000). Last but not least, effective implementation of this plan requires the involvement of local governments and stakeholders and especially the organizations that manage the PNAs.

\section{Acknowledgements}

The authors gratefully acknowledge the research support provided by the Catalan Centre for Integrated Rural Development (Centre de Desenvolupament Integrat de Catalunya, CEDRICAT) Foundation, including the doctoral programme "Talent-Empresa" (Marta PallarèsBlanch). Her work has been done within the framework of the UAB Ph.D. programme in Geography. We also appreciate the funding support by project grants SEJ 2007-63024, CSO2011-28480 and CSO 2009-08271. We also wish to recognize the contributions made by those who reviewed this article.

\section{References}

[1] Alamon, N., Guardia, C., Pallarès-Blanch, M., Pallarès, I. \& Paül, D. (2012). Potencialidades del desarrollo rural sostenible: la artesanía alimentaria en el Pirineo. In Proceedings of XVI Coloquio de Geografía Rural de la Asociación de Geógrafos Españoles "Investigando en rural" May 10-12 2012 , Sevilla.

[2] Arkleton Trust (1985). Part-time Farming in the Rural Development of Industrialized Countries. Langholm, Dumfriesshire: The Arkleton Trust.

[3] Bell, M. \& Ward, G. (2000). Comparing temporary mobility with permanent migration. Tourism Geographies: Tourism Geography, 2 (1):87-107. Doi: $10.1080 / 146166800363466$.

[4] Berry, B. J. L., (1976a). The counter-urbanization process: urban America since 1970. Urban Affairs Annual Review 11: 17-30.

[5] Berry, B. J. (1976b). Urbanization and Counter-urbanization. London: Sage.

[6] Berry, B. J. (1978). The Counter-urbanization Process: How General? In N. Hansen (ed), Human Settlement System (pp. 25-50). Cambridge: Ballinger.

[7] Bertrand, C. \& Bertrand, G. (2002). Une géographie traversière. L'environnement à travers territories et temporalités. Paris: Éditions Arguments.

[8] Barros, F. (2008). Anàlise do Fenòmeno da Naturbanizaçao ao Nivel do PDM - Aplicaçao a Terras de Bouro. Braga: Universidade do Minho.

[9] Bourdeau, P., Daller, J. F. \& Martin, N. (2012). Migrations d'agrément: du tourisme à l'habiter. Paris: L'Harmattan.

[10] Bowler, I. R., Bryant, C. R. \& Nellis, M. D., eds. (1992). Contemporary Rural Systems in Transition. Vol. 2 Economy and Society. Totnes: CABI publishing.

[11] Boyle, P., Halfacree, K. \& Robinson, V. (1998). Exploring Contemporary Migration. Longman, Harlow.

[12] Brown, D. L. \& Cromartie, J. B. (2004). The Nature of Rurality in Postindustrial Society. In Champion, A. G. \& Hugo, G., eds., New Forms of Urbanization: Beyond the Urban-rural Dichotomy (pp. 269-285). Farnham: Ashgate.

[13] Brown, D. L. \& Wardell, J. M., eds. (1980). New Directions in Urban-Rural Migration. The Population Turnaround in Rural America. New York: Academic Press. 
[14] Bunce, M. (1994). The countryside idyll: Anglo-American images of landscape. London: Routledge.

[15] Camarero, L. A. (1993). Del éxodo rural y del éxodo urbano. Madrid: Ministerio de Agricultura, Pesca y Alimentación.

[16] Cànoves, G., Villarino, M. \& Herrera, L. (2006). Políticas públicas, turismo rural y sostenibilidad: difícil equilibrio. In Boletín de la Asociación de Geógrafos Españoles 41, 199-220.

[17] Casado-Diaz, M. A. (2004). Second homes in Spain. In Hall, C. M. \& Müller, D. K., eds., Tourism, mobility and second homes. Between Elite Landscape and Common Ground. (pp. 215-233). Trowbridge: Cromwell Press.

[18] Castro, J. \& Mora, J. (2011). La inmigración en España: procedencia y distrución interior. Migraciones internacionales y co-desarrollo: el caso de Ecuador (conclusiones y respuestas del Seminario de Expertos sobre el desarrollo y derechos de las personas: el caso de Ecuador, en Madrid y en Quito en 2011. Universidad Rey Juan Carlos, 2011.

[19] Cloke, P. (1977). An index of rurality for England and Wales, Regional Studies, 11(1), 3146. Doi: 10.1080/09595237700185041.

[20] Cloke, P. (1985). Counter-urbanisation: a rural perspective. Geography 70, 13-23.

[21] Cloke, P. (2006). Conceptualizing rurality. In Cloke, P., Marsden, T. \& Mooney, P., eds., Handbook of rural studies (pp. 18-28). London: Sage.

[22] Cloke, P. \& Little, J. (1990). The rural state? Limits to planning in rural society. Oxford: Clarendon Press.

[23] Cloke, P. \& Thrift, N. (1990). Class and change in rural Britain. In Marsden, T., Lowe, P. \& Whatmore, S., eds., Rural Restructuring. Global Processes and Their Responses (pp. 165-181). London: David Fulton Publications.

[24] Cloke, P., Philips, M. \& Thrift, N. (1995). The new middle classes and the social constructs of rural living. In Butler, T., Savage, M., eds., Social change and the middle class (pp. 220-238). London: UCL Press.

[25] Copus, A \& Dax, T. (2010). Conceptual Background and Priorities of European Rural Development Policy. Rural Development Impacts. WP1 Priorities in RD Policies Deliverables. Funded by the 7th Framework Programme for Research and Technology Development of the European Commission Project no. 213034. Accessed from http://www.rudi-europe.net/reportspublications.html [Retrieved 28-10-13].

[26] Corraliza, J. A., Garcia, J. \& Valero, E. (2002). La imagen social de los parques naturales. In Los Parques Naturales en España: conservación y disfrute (pp. 129-204). Madrid: Fundación Alonso Escudero.

[27] Czerny, M., Lecka, I. \& Wujek, M. (2009). The development of urbanization in the neighbourhood of Kampinoski National Park. In Prados, M. J., ed., Naturbanization: New identities and processes for rural-natural areas (pp. 29-45). London: Taylor \& Francis.

[28] Champion, A. G., ed., (1989). Counterurbanization. The Changing Pace and Nature of Population Deconcentration. London: Edward Arnold.

[29] Champion, A. G. (1995). Internal migration, counterurbanization and changing population distribution. In Hall, R., White, P., eds., Europe's Population: Towards the Next Century. (pp.99-129). London: UCL Press.

[30] Champion, T., Coombes, M. \& Fotheringham, S., eds. (1998). Urban exodus. London: CPRE.

[31] Champion, A. G. \& Hugo, G. (2004). Introduction: Moving Beyond the Urban-Rural Dichotomy in Champion, A. G. \& Hugo, G., eds., New Forms of Urbanization: Beyond the Urban-rural Dichotomy (pp. 3-25). Farnham: Ashgate. 
[32] Chipeniuk, R. (2004). Planning for amenity migration in Canada: Current capacities of interior British Columbian mountain communities. Mountain Research and Development 24(4): 327-335. Doi: 10.1659/0276-4741.

[33] Dahms, F. \& McComb, J. (1999). 'Counterurbanization', interaction and functional change in a rural amenity area: A Canadian example. Journal of Rural Studies, 15(2): 129-146. Doi: 10.1016/S0743-0167(98)00056-4.

[34] Dam van, F., Heins, S., Elbersen, B. S. (2002). Lay discourses of the rural and stated and revealed preferences for rural living. Some evidences of the existence of a rural idyll in the Netherlands. Journal of Rural Studies 18 (4): 461-476. Doi: 10.1016/S07430167(02)00035-9.

[35] Darling, E. (2005). The city in the country: Wilderness gentrification and the rent gap. Environment and Planning 37(6), 1015-1032. Doi: 10.1068/a37158.

[36] Debarbieux, B. \& Price, M. F. (2012). Mountain Regions: A Global Common Good? Mountain Research and Development 32(Suppl), S7-S11. Doi: 10.1659/MRD-JOURNALD-11-00034.S1.

[37] Deller, S. C., Tsung-Hsiu, T., Marcoullier, D., \& English, D. B. K., eds. (2001). The role of amenities and quality of life in rural economic growth. American Journal of Agricultural Economics, 83(2): 352-365. Doi: 10.1111/0002-9092.00161.

[38] Dijst, M., Elbersen, B. \& Willis, K. (2005). The Challenge of Multi-functional Land Use in Rural Areas. Editorial Journal of Environmental Planning and Management, 48(1): 3-6. Doi: 10.1080/0964056042000308120.

[39] Doctor, A. \& Prados, M. J. (2012). ¿Conservar o construir? El desarrollo de la edificación en las áreas de influencia de los ENP de Doñana y Sierra Nevada. XVI Coloquio de Geografía Rura. (pp. 107-115). Sevilla: Asociación de Geógrafos Españoles,.

[40] Domínguez García, M. D., Swagemakers, P., Bock, B. B., Simón Fernández, X. (2012). Making a Living: Grassroots development initiatives, natural resource management and institutional support in Galicia, Spain. European Countryside, 4(1), 17-30. Doi: 10.2478/v10091-012-0011-x.

[41] Elbersen, B. S. (2001). Nature on the Doorstep. The Relationship between Protected Natural Areas and Residential Activity in the European Countryside. Wageningen: ALTERRA.

[42] Elbersen, B. (2005). Combining Nature Conservation and Residential Development in The Netherlands, England and Spain. Journal of Environmental Planning and Management, 48(1), 37-63. Doi: 10.1080/0964056042000308148.

[43] Elbersen, B. \& Prados, M. J. (1999). Desarrollo rural y calidad de vida en el entorno del Parque Nacional de Doñana. Estudios Regionales 55, 47-76.

[44] Esparcia, J., Noguera, J. I. \& Pitarch, M. D. (2000). LEADER en España: desarrollo rural, poder, legitimación, aprendizaje y nuevas estructuras. Documents d'Anàlisi Geogràfica, 37, 95-113.

[45] Fabes, R., Worsley, L., \& Howard, M. (1983). The myth of the rural idyll. Leicester: Child Poverty Action Group.

[46] Fernández Márquez, M. \& Salinas Fernández, J. A. (2009). Impacto socioeconómico del espacio natural protegido de Sierra Nevada. In Sunyer, C., ed., Eco-emprendedores: Retos para la puesta en valor de los espacios protegidos. Madrid: TERRA centro para la política ambiental.

[47] Figueiredo, E. (2009). One rural, two visions - Environmental issues and images on rural areas in Portugal, European countryside 1(1), 9-21. Doi: 10.2478/v10091-009-0002-8.

[48] Fielding, A. J. (1982). Counterurbanization in Western Europe. Progress in Planning, 17(1), 1-52. Doi: 10.1016/0305-9006(82)90006-X. 
[49] Fielding, T. (1992). Migration and social change. In Champion, A., Fielding, T., eds., Migration processes and patterns. Vol. I: Research progress and prospects (pp. 225-247). London: Belhaven Press.

[50] Fielding, A. J. (1993). Migration and the metropolis: an empirical and theoretical analysis of inter-regional migration to and from South-East England. Progress in Planning 39(2), 72-66. Doi: 10.1016/0305-9006(93)90006-F.

[51] Findlay, A. \& Rogerson, R. (1993). Migration, places and quality of life (voting with their feet?). In T. Champion, ed., Population matters. The local dimension (pp. 33-49). London: Paul Chapman.

[52] Flores, D. \& Barroso, M. (2012). The Tourism like a Strategy of Sustainable Rural Development. The Andalusian Nature Reserves. Revista de Estudios Empresariales. Segunda época, 1(1), 59-83.

[53] Friedmann, J. (2002). The prospect of cities. Minneapolis: University of Minnesota Press.

[54] Frey, W. H. (1993). The new urban revival in the United States. Urban Studies, 30(4-5), 741-774. Doi: 10.1080/00420989320081901.

[55] Fuguita, G. V. \& Johansen, H. E. (1984). The Changing Rural Village in America. Demographic and Economic Trends since 1950. Cambridge: Balliger Publishing Company.

[56] Gallent, N., Mace, A. \& Tewdwr-Jones, M., eds. (2005). Second Homes: European Perspectives and UK Policies. Farnham: Ashgate.

[57] Ganau, J. et. al. (2013). Evolución de las zonas de montaña españolas. Documento de Trabajo inédito. Jornadas "Las políticas de montaña en España: una asignatura pendiente". 24-25 October 2013. Càtedra Repsol de Competitivitat i Desenvolupament Regional de la Universitat de Lleida.

[58] García, A. \& García, J. (2002). La cuestión rural: patología urbanística del espacio rústico. Ciudad y Territorio. Estudios Territoriales, (132), 277-323.

[59] García Ramón, M. D., Tulla, A. F. \& Valdovinos, N. (1995). Geografía Rural. Madrid: Síntesis.

[60] Gasson, R. (1986). Part Time Farming Strategy for Survival?. Sociologia Ruralis 26(3/4): 364-76. Doi: 10.1111/j.1467-9523.1986.tb00792.x.

[61] Gessa, A. \& Toledano, N. (2011). Turismo, Emprendimiento y Sostenibilidad en los Espacios Naturales Protegidos el caso de Andalucía - España. Estudios y Perspectivas en Turismo Volumen 20(5), 1154-1174.

[62] Ghose, R. (2004). Big sky or big sprawl? Rural gentrification and the changing cultural landscape of Missoula, Montana. Urban Geography 25(6), 528-549. Doi: 10.2747/02723638.25.6.528.

[63] Gosnell, H. \& Abrams, J. (2011). Amenity migration: diverse conceptualizations of drivers, socioeconomic dimensions, and emerging challenges. GeoJournal, 76(4), 303-322. Doi: 10.1007/s10708-009-9295-4.

[64] Gorton, M., White, J. \& Chaston, I. (1998). Counteurbanisation, fragmentation ant the paradox of the rural idyll (pp. 215-235). In P. Boyle, K. Halfacree, Migration into rural areas. Theories and issues. Chichester: Wiley.

[65] Gude, P. H., Hansen, A. J., Rasker, R. \& Maxwell, B. (2006). Rates and drivers of rural residential development in Greater Yellowstone. Landscape and Urban Planning 77(1-2): 131-151. Doi: 10.1016/j.landurbplan.2005.02.004.

[66] Guirado, C. G. (2011). Tornant a la muntanya [PhD theses]. Barcelona: Universitat Autònoma. 
[67] Halfacree, K. (1994). The importance of 'the rural' in the constitution of counterurbanization: Evidence from England in the 1980s. Sociologia Ruralis 34(2-3), 164-189. Doi: 10.1111/j.1467-9523.1994.tb00807.x.

[68] Halfacree, K. (1996). Out of place in the countryside: travellers and the 'rural idyll', Antipode, 29(1), 42-72. Doi: 10.1111/j.1467-8330.1996.tb00671.x.

[69] Halfacree, K. (1997). Contrasting roles for the post-productivist countryside. A postmodern perspective on counter-urbanization (pp.70-93). In Cloke, P. \& Little, J., eds., Contested Countryside Cultures. Otherness, Marginalization and Rurality. London: Routledge.

[70] Halfacree, K. (2001). Going 'back-to-the-land' again: extending the scope of counterurbanization. Espace. Population. Societies 1-2, 161-170.

[71] Halfacree, K. (2003). Landscapes of rurality: rural others/other rurals (pp. 141-169). In Robertson, I. \& Richards, P., eds., Studying cultural landscapes. London: Arnold.

[72] Halfacree, K. H. (2006). From dropping out to leading on? British counter-cultural back-tothe-land in a changingrurality. Progress in Human Geography, 30(3), 309-336. Doi: 10.1191/0309132506ph609oa.

[73] Halfacree, K. (2007). Still surprises in store. Revisiting the ordinary in rural geography Documents d'Anàlisi Geogràfica, 50, 87-103.

[74] Halfacree, K. (2012). Heterolocal Identities? Counter-Urbanisation, Second Homes, and Rural Consumption in the Era of Mobilities. Population, Space and Place, 18(2), 209-224. Doi: $10.1002 / p s p .665$.

[75] Halliday, J., Coombes, M. (1991). In search of counterurbanisation: some evidence from Devon on the relationship between patterns of migration and motivation. Journal of Rural Studies 11(4), 433-446. Doi: 10.1016/0743-0167(95)00032-1.

[76] Harper, S. (1991). People moving to the countryside: case studies of decision-making (pp. 22-37). In Champion, T. \& Watkins, Ch., eds., People in the Countryside. Studies of Social Change in Rural Britain. London: Paul Chapman Publishing Ltd.

[77] Hoggart, K., (1997). Rural migration and counterurbanization in the European periphery: the case of Andalucia. Sociologia Ruralis 37(1), 134-153. Doi: 10.1111/1467-9523.00040.

[78] Jaillet, M. C. (2004). 'Developpement et recomposition des espaces periurbains'. In "Périurbain, périrural?" Lutte contre les discriminations, rénovation urbaine/pays touristiques. Bordeaux: Pays et quartiers d'Aquitanie.

[79] Johnson, J. D. \& Rasker, R. (1995). The role of economy and quality of life values in rural business location. Journal of Rural Studies 11(4), 405-416. Doi: 10.1016/07430167(95)00029-1.

[80] Kaplan, R. \& Austin, M. E. (2004). Out in the country: sprawl and the quest for nature nearby. Landscape and Urban Planning 69(2-3), 235-243. Doi: 10.1016/j.landurbplan.2003.09.006.

[81] Kay, C. (2008). Reflections on Latin American Rural Studies in the Neoliberal Globalization Period: A New Rurality? Development and Change 39(6): 915-943. Doi: 10.1111/j.1467-7660.2008.00518.x.

[82] Krannich, R., \& Petrzelka, P. (2003). Tourism and natural amenity development: Real opportunities? In Brown, D. L. \& Swanson, L. E., eds., Challenges for Rural America in the Twenty-First Century (pp. 190-199). University Park: Pennsylvania State University Press.

[83] Lefebvre, H. (2003). The urban revolution. Minneapolis: University of Minnesota Press.

[84] Lewis, G. J. (1979). Rural communities - a Social Geography, Newton Abbot: David \& Charles Ltd.

[85] Ley 45/2007, de 13 de diciembre, para el desarollo sostenible del medio rural. 
[86] Little, J. (1999). Otherness, representation and the cultural construction of rurality. Progress in Human Geography 23(3): 437-442. Doi: 10.1177/030913259902300307.

[87] Loffler, R. \& Steinecke, E. (2006). Counterurbanization and its socioeconomic effects in high mountain areas of the Sierra Nevada (California/Nevada). Mountain Research and Development, 26(1), 64-71. Doi: 10.1659/0276-4741(2006)026[0064:CAISEI]2.0.CO;2.

[88] Loffler, R. \& Steinecke, E. (2007). Amenity migration in the US Sierra Nevada. Geographical Review, 97(1), 67-88.

[89] Lonsdale, R. \& Holmes, H., eds. (1981). Settlement Systems in Sparsely Populated Regions: the United States and Australia. York: Pergamon Press.

[90] Lourenço, J. M., Quental, N., Barros, F. (2009). Naturbanization and sustainability at Peneda-Gerês National Park (pp.45-75). In Prados, M. J. (ed.), Naturbanization: New identities and processes for rural-natural areas. London: Taylor \& Francis Group.

[91] Lowe, P., Murdoch, J., Marsden, T., Munton, R. \& Flynn, A. (1993). Regulating the new rural spaces: The uneven development of land. Journal of Rural Studies, 9(3), 205-222. Doi: 10.1016/0743-0167(93)90067-T.

[92] Llei 2/1983, de 9 de març, d'alta muntanya.

[93] Llei 24/2001, de 31 de desembre, de reconeixement de l'Alt Pirineu i Aran com a àrea funcional de planificació, mitjançant la modificació de l'article 2 de la Llei 1/1995, per la qual s'aprova el Pla territorial general de Catalunya. DOGC núm. 3563, 29.01.2002.

[94] Marcouiller, D. W., Lapping, M. B. \& Furuseth, O. J. (eds.) (2011). Rural Housing, Exurbanization, and Amenity-driven Development: Contrasting the "haves" and the "have Nots". Farnham: Ashgate.

[95] Marsden, T. (1990). Towards the Political Economy of Pluriactivity. Journal of Rural Studies 6(4), 375-82. Doi: 10.1016/0743-0167(90)90050-I.

[96] Marsden, T. (2003). The condition of rural sustainability: Issues in the governance of rural space in Europe (pp. 19-38). In Kasimis, Ch. \& Stathakis, G., eds, The Reform of the CAP and Rural Development in Southern Europe. Aldershot: Ashgate.

[97] Martínez Vega, J. \& Romero Calcerrada, R. (2003). Repercusión de los Espacios Naturales Protegidos en la economía rural española. Serie Geográfica, 11, 41-60.

[98] Mitchell, C. J. A. (2004). Making sense of counterurbanization. Journal of Rural Studies 20(1), 15-34. Doi: 10.1016/S0743-0167(03)00031-7.

[99] Mehnen, N., Mose, I. \& Strijker, D. (2009). Governance in Protected Areas - current state of research and existing research gaps. $1^{\text {st }}$ International Conference on Landscape Economics European Consortium for Landscape Economics, CEEP, July 2-4, 2009. Wien.

[100] Mingay, G. E., ed. (1994). The rural idyll. London: Routledge.

[101] Morris, C. \& Kirwan, J. (2011). Ecological embeddedness: An interrogation and refinement of the concept within the context of alternative food networks in the UK. Journal of Rural Studies 27, 322-330. Doi: 10.1016/j.jrurstud.2011.03.004.

[102] Moss, L. A. G. (2006). The Amenity Migrants: Ecological Challenge to Contemporary Shangri-La (pp. 3-26). In Moss, L. A. G., ed., The Amenity Migrants Seeking and Sustaining Mountains and their Cultures. Wallingford: CAB International.

[103] Moyano Estrada, E. (2005). Nuevas Orientaciones de la Política Europea de Desarrollo Rural. A propósito del nuevo reglamento de desarrollo rural. Revista de Fomento Social 238, 219-241.

[104] Müller, D. K. (2006). Amenity Migration and Tourism Development in the Tärna Mountains, Sweden (pp. 245-259). In Moss L. A. G., ed., The Amenity Migrants Seeking and Sustaining Mountains and their Cultures. Wallingford: CAB International. 
[105] Murdoch, J. \& Pratt, A. C. (1993). 'Rural Studies: Modernism, Postmodernism and the "Postrural". Journal of Rural Studies 9(4), 411-27. Doi: 10.1016/0743-0167(93)90053M.

[106] Murdoch, J. (1998). Counterurbanisation and the countryside: some causes and consequences of urban to rural migration. Cardiff: Department of City and Regional Planning, Cardiff University.

[107] Murdoch, J. (2006). Networking rurality: emergent complexity in the countryside (pp. 171184. In Cloke, P., Marsden, T., Mooney, P. H., eds., Handbook of Rural Studies, London: Sage.

[108] Naughton-Treves, L., Holland, M. \& Brandon, K. (2005). The Role of Protected Areas in Conserving Biodiversity and Sustaining Local Livelihoods. Annual Review of Environmental Resources 30, 219-252. Doi: 10.1146/annurev.energy.30.050504.164507.

[109] Nechodom, M. (2005). Institutional and Policy Contexts of Biosphere Reserves: Potential Roles for Social Science in Sustainable Development Strategies. In Third Thematic Workshop: Sustainable Land Use and Natural Resources Management, Sierra Nevada Biosphere Reserve (pp. 195-211). Paris: UNESCO.

[110] Nogué, J. (1988). El fenómeno neorrural. Agricultura y Sociedad, 47, 145-175.

[111] Nogué, J. \& de San Eugenio, J. (2009). Pensamiento geográfico versus teoría de la comunicación. Hacia un modelo de análisis comunicativo del paisaje Documents d'Anàlisi Geogràfica. 55, 27-55.

[112] Norris, M., Paris, C. \& Winston, N. (2010). Second homes within Irish housing booms and busts: North - South comparisons, contrasts, and debates. Environment and Planning C: Government and Policy 28(4), 666-680. Doi: 10.1068/c08134.

[113] Otterstrom, S. M. \& Shumway, J. M. (2003). Deserts and oases: The continuing concentration of population in the American Mountain West. Journal of Rural Studies, 19(4): 445-462. Doi: 10.1016/S0743-0167(03)00028-7.

[114] de Pablo, J. \& Berino Díaz, L. C. (2002). El enfoque multifuncional y el desarrollo rural en Andalucía (España): estudios de casos de los grupos de acción local de Alpujarra y de Filabres - Sierra Alhamilla (Almería). Cuadernos de Desarrollo Rural, 48, 7-33.

[115] Pahl, R. (1966). The rural-urban continuum. Sociologia Ruralis, 6(3), 299-327. Doi: 10.1111/j.1467-9523.1966.tb00537.x.

[116] Pallarès-Barberà, M. \& Vera, A. (2000). Incrustación industrial y medio innovador en la comarca del Berguedà (pp. 195-210). In Alonso, J.L.; Méndez, R., eds., Innovación, pequeña empresa y desarrollo local en España. Madrid: Civitas.

[117] Pallarès-Barberà, M. \& Vera, A. (2001). Espais econòmics i milieus innovatius industrials a la comarca del Berguedà. Documents d'Anàlisi Geogràfica, 38, 33-53.

[118] Pallarès-Barberà, M., Pallarès-Blanch, M. \& Tulla, A. F. (2003). Capital social I treball de les dones als Pirineus. El cas de l'Alt Urgell. Barcelona: ICD, Generalitat de Catalonia.

[119] Pallarès-Barberà, M., Tulla, A. F. \& Vera, A. (2004). Spatial loyalty and territorial embeddedness in the multi-sector clustering of the Berguedà region in Catalonia (Spain). Geoforum, 35(5): 635-649. Doi: 10.1016/j.geoforum.2004.03.004.

[120] Pallarès-Blanch, M. (2009). The benefits of Nature Reserve Areas in local development: An opportunity to develop a sustainable strategy in peripheral areas. In Prados, M. J., ed., Naturbanization: New identities and processes for rural-natural areas. London: Taylor \& Francis.

[121] Pallarès-Blanch, M. (2012). Natural Protected Areas and Rural/Local Development: A Sustainable Strategy in Remote Areas. Urbani izziv, 23(2 special Issue): S87-S96. Doi: 10.5379/urbani-izziv-en-2012-23-supplement-2-007. 
[122] Paniagua, A. (2002a). Counterurbanisation and new social class in rural Spain: the environmental and rural dimension revisited. Scottish Geographical Journal 118(1), 118. Doi: $10.1080 / 00369220218737133$.

[123] Paniagua, A. (2002b). Urban-rural migration, tourism entrepreneurs and rural restructuring in Spain. Tourism geographies 4(2), 349-371. Doi: $10.1080 / 14616680210158128$.

[124] Paniagua, A. (2008). The environmental dimension in the constitution of new social groups in an extremely depopulated rural area of Spain (Soria). Land Use Policy 25(1), 17-29. Doi: 10.1016/j.landusepol.2007.02.001.

[125] Phillips, M. (2004). Other geographies of gentrification. Progress in Human Geography. 28(1), 5-30. Doi: 10.1191/0309132504ph458oa.

[126] Pintos, R. (2005). Sustainable Development and Global Change: How they are put into effect in the Andalusian Network of Natural Protected Areas (pp. 14-17). In Global change impacts in mountain biosphere reserves. Paris: UNESCO.

[127] Prados, M. J. \& Cunningham, C. (2002). Calidad ambiental y nuevas pautas en la movilidad residencial de la población: Propuesta metodológica para el estudio de procesos de naturbanización (pp. 425-433). In Los espacios rurales entre el hoy y el mañana. Santander: Universidad de Cantabria.

[128] Prados, M. J. (2005). Territorial recognition and control of changes in dynamic rural areas. Journal of Environmental Planning and Management 48(1), 65-83. Doi: $10.1080 / 0964056042000308157$.

[129] Prados, M. J. (2009). Conceptual and methodological framework of naturbanization (pp. 11-28). In Prados, M. J., ed., Naturbanization: New identities and processes for ruralnatural areas. London: Taylor \& Francis.

[130] Prados, M. J. \& Tulla, A. F. (2009). New rural landscapes altered by naturbanization (pp. 109-125). In Robinson, G., Molinero, F., Guerra, J. C., eds., III Anglo-Spanish Rural Geography Conference. Canterbury: Asociación de Geógrafos Españoles \& Association of British Geographers.

[131] Prados, M. J. \& Giusti, M. (2010). Naturaleza y espacio construido. Un análisis exploratorio de la naturbanización en Andalucía (pp. 304-320). In Delgado Viñas, C., ed., Espacios y paisajes urbanos: reflexionar sobre su presente para proyectar su futuro. Santander: Asociación de Geógrafos Españoles; Universidades de Cantabria, de Oviedo y del País Vasco.

[132] Prados, M. J. \& del Valle, C. (2010). Naturbanización y cambios en la población de los espacios naturales de Doñana y Sierra Nevada. Documents d Anàlisi Geogràfica 56(3), 437-462.

[133] Price, M. F., Moss, L. A. G. \& Williams, P. W. (1997). Tourism and amenity migration (pp. 249-280). In Messerly, B. \& Ives, J. D., eds., Mountains of the world: a global priority. Carnforth: Parthenon Publishing Group.

[134] Pumain, D. (2004). An evolutionary approach to settlement systems (pp. 231-249). In Champion, A. G. \& Hugo, G., eds., New Forms of Urbanization: Beyond the Urban-rural Dichotomy. Farnham: Ashgate.

[135] Rasker, R. \& Hansen, A. J. (2000). Natural amenities and population growth in the Greater Yellowstone region. Human Ecology Review, 7(2), 30-40.

[136] Ramos, E. \& Delgado, M. M. (2005). El enfoque territorial del desarrollo rural de las aportaciones teóricas a su aplicación en Andalucía (pp. 43-65). In Delgado, M., López, M. C. \& Romero, J. J., eds., Economía y territorio: la Comunidad Autónoma Andaluza. Bilbao: Desclée de Brouwer.

[137] Santamarina, B. (2005). La patrimonialización de la naturaleza: figuras (espacios protegidos) y discursos (desarrollo sostenible), (pp. 25-44). In Fernández, J. P. \& Florido 
del Corral, D., eds., ¿Protegiendo los recursos? Áreas protegidas, poblaciones locales y sostenibilidad. Sevilla, Fundación El Monte.

[138] Sage, C. (2003). Social embeddedness and relations of regard alternative 'good food' networks in south-west Ireland. Journal of Rural Studies, 19(1), 47-60. Doi: 10.1016/S0743-0167(02)00044-X.

[139] Saint Onge, J. M., Hunter, L. M. \& Boardman, J. D. (2007). Population growth in highamenity rural areas: Does it bring socioeconomic benefits for long-term residents? Social Science Quarterly, 88(2), 367-381. Doi: 10.1111/j.1540-6237.2007.00462.x.

[140] Sedlacek, S., Kurka, B. \& Maier, G. (2009). Regional identity: A key to overcome structural weaknesses in peripheral rural regions. European Countryside 1(4), 180-201. Doi: 10.2478/v10091-009-0015-3.

[141] Shucksmith, M. (1983). Second homes - a framework for policy. Town Planning Review 54(2), 174-193.

[142] Sofranko, A. J. \& Williams, J. D. (1980). Rebirth of Rural America: Rural Migration in the Midwest. North Central Region Centre for Rural Development. Ames: lowa State University.

[143] Solana, A. M. (2008). El encanto de lo rural, los términos del debate sobre la mión hacia áreas rurales desde la geografía británica y las contribuciones españolas. Un estado de la cuestión Revista bibliográfica de Geografía y ciencias sociales 13(776). Retrieved from http://www.ub.edu/geocrit/b3w-776.htm [12-08-2013].

[144] Solana, A. M. (2010). Rural Gentrification in Catalonia, Spain? A Case Study of Migration, Social Change and Conflicts in the Empordanet area. Geoforum, 41(3), 508-517. Doi: 10.1016/j.geoforum.2010.01.005.

[145] Solé, A., Guirado, C. \& Solana, M. (2012). Cambios en la dinámica demográfica y migratoria del Pirineo catalán. Análisis sociolaboral de la población extranjera. AGER. Journal of depopulation and rural development studies: 12 , 51-90. Doi: 10.4422/ager.2011.02.

[146] Soriano, J. M. \& Tulla, A. F. (2003). El repoblament del Pirineu Català: Desig o realitat? Mètode 36, 65-70.

[147] Terán, F. de (1982). Planeamiento urbano en la España contemporánea (1900-1980). Madrid: Alianza Universidad Textos.

[148] Tolón Becerra, A. \& Lastra Bravo, X. (2009a). Los alimentos de calidad diferenciada: una herramienta para el desarrollo rural sostenible. $M+A$. Revista Electrónica de Medioambiente, Norteamérica. 6, 1-23.

[149] Tolón Becerra, A. \& Lastra Bravo, X. (2009b). Los alimentos de calidad diferenciada: una herramienta para el desarrollo rural sostenible. $M+A$. Revista Electrónic@ de Medio Ambiente 6, 45-67.

[150] Troitiño, M. A., de Marco, F. J., García, M., del Río, M. I., Carpio, J., de la Calle, M. \& Abad, L. D. (2005). Los espacios protegidos en España: Significación e incidencia socioterritorial. Boletín de la A.G.E. 39, 227-265.

[151] Tulla, A. F. (1991). Women and family farms in Catalonia, Iberian Studies 20(1-2), 62-80.

[152] Tulla, A. F. \& Pallarès-Blanch, M. (2008). La mobilitat quotidiana a l'Alt Pirineu i Aran. In IERMB: Papers (48), 100-114.

[153] Tulla, A. F., Pallarès-Barberà, M. \& Vera, A. (2009). Naturbanization and local development in the mountain areas of the Catalan Pyrenees (pp. 75-92). In Prados, M. J., ed., Naturbanization: New identities and processes for rural-natural areas. London: Taylor \& Francis. 
[154] Tulla, A. F., Prados, M. J. \& Pallarès-Blanch, M. (2012). New Rural Landscapes Altered by Naturbanization in Spain: Andalusia and Catalonia (pp. 52-53). In Zapletalová, J; Vaishar, A., eds, Multifunctional Rural Development. Brno: Mendel University.

[155] Williams, A. \& Jobes, P. (1990). Economic and quality-of-life considerations in urban-rural migration, Journal of Rural Studies 6(2), 187-194. Doi: 10.1016/0743-0167(90)90005-S.

[156] Woods, M. (2011). Rural geography: Processes, responses and experiences in rural restructuring. London: Sage. 